\title{
Robo-2 Controls the Segregation of a Portion of Basal Vomeronasal Sensory Neuron Axons to the Posterior Region of the Accessory Olfactory Bulb
}

\author{
Janet E. A. Prince, ${ }^{1,2}$ Jin Hyung Cho, ${ }^{1,2}$ Emilie Dumontier, ${ }^{1,2}$ William Andrews, ${ }^{3}$ Tyler Cutforth, ${ }^{4}$ Marc Tessier-Lavigne, ${ }^{5}$ \\ John Parnavelas, ${ }^{3}$ and Jean-François Cloutier ${ }^{1,2}$ \\ ${ }^{1}$ Montreal Neurological Institute, Centre for Neuronal Survival, Montréal, Québec H3A 2B4, Canada, ${ }^{2}$ Department of Neurology and Neurosurgery, McGill \\ University, Montréal, Québec H3A 2B4, Canada, ${ }^{3}$ Department of Cell and Developmental Biology, University College London, London WC1E 6BT, United \\ Kingdom, ${ }^{4}$ Department of Molecular, Cell \& Developmental Biology, University of California, Santa Cruz, Santa Cruz, California 95064, and ${ }^{5}$ Division of \\ Research, Genentech Inc., South San Francisco, California 94080
}

The ability of sensory systems to detect and process information from the environment relies on the elaboration of precise connections between sensory neurons in the periphery and second order neurons in the CNS. In mice, the accessory olfactory system is thought to regulate a wide variety of social and sexual behaviors. The expression of the Slit receptors Robo-1 and Robo-2 in vomeronasal sensory neurons (VSNs) suggests they may direct the stereotypic targeting of their axons to the accessory olfactory bulb (AOB). Here, we have examined the roles of Robo-1 and Robo- 2 in the formation of connections by VSN axons within the AOB. While Robo-1 is not necessary for the segregation of VSN axons within the anterior and posterior regions of the AOB, Robo-2 is required for the targeting of some basal VSN axons to the posterior region of the AOB but is dispensable for the fasciculation of VSN axons. Furthermore, the specific ablation of Robo-2 expression in VSNs leads to mistargeting of a portion of basal VSN axons to the anterior region of the AOB, indicating that Robo-2 expression is required on projecting VSN axons. Together, these results identify Robo-2 as a receptor that controls the targeting of basal VSN axons to the posterior AOB.

\section{Introduction}

The accessory olfactory system plays an important role in the regulation of sexual behavior and social dominance in mice (Dulac and Wagner, 2006; Zufall and Leinders-Zufall, 2007). Sensory neurons located in the vomeronasal organ $(\mathrm{VNO})$ at the base of the nasal septum express vomeronasal receptors (VRs) and detect compounds that affect various mouse behaviors including male-to-male aggression and kin recognition. Two large families of VRs, V1Rs and V2Rs, have been described and their expression correlates with the location of vomeronasal sensory neuron (VSN) cell bodies within the sensory epithelium (Dulac

Received Aug. 12, 2009; revised Sept. 23, 2009; accepted Sept. 25, 2009.

This work was supported by the Canadian Institutes for Health Research, the Fonds Québécois pour la Recherche sur la Nature et les Technologies, the Montreal Neurological Institute Centre of Excellence in Commercialization and Research (J.-F.C.), and a grant from the Wellcome Trust, Programme Grant 074549 (J.P.). J.E.A.P. held a Master's studentship from the Natural Sciences and Engineering Research Council of Canada and holds a Ph.D. studentship from the Fonds Québécois pour la Recherche sur la Nature et les Technologies. J.H.C. holds a studentship from the Fonds de Recherche en Santé du Québec. J.-F.C. holds a Canada Research Chair in developmental neurobiology. We thank Don Van Meyel and David Ginty for their comments on this manuscript. We are grateful to Edward Ruthazer for advice on statistical analysis and to members of the Cloutier laboratory for helpful discussion and technical advice. We are thankful to David Ornitz for Slit CDNA clones, Alain Chédotal for Robo and Slit-3 cDNA clones, and Randall Reed and Roman Giger for $\mathrm{G}_{\alpha \mathrm{i} 2}$ and $\mathrm{G}_{\alpha 0}$ CDNAs. We thank Catherine Dulac for her generous gift of the EC2-tau-lacZ and VN12-tau-lacZ mouse lines, Jeffrey Esko for providing us with the slit-3 mutant mice with permission from David Ornitz, and Frédéric Charron for Nestin-Cre mice.

Correspondence should be addressed to Jean-François Cloutier, Montreal Neurological Institute, Centre for Neuronal Survival, 3801 University, Montréal, QC H3A 2B4, Canada. E-mail: jf.cloutier@mcgill.ca.

DOI:10.1523/JNEUROSCI.3948-09.2009

Copyright $\odot 2009$ Society for Neuroscience ～0270-6474/09/2914211-12\$15.00/0 and Axel, 1995; Matsunami and Buck, 1997; Herrada and Dulac, 1997; Ryba and Tirindelli, 1997; Pantages and Dulac, 2000; Rodriguez et al., 2002). Sensory neurons with cell bodies located in the apical region of the $\mathrm{VNO}$ express $\mathrm{V} 1 \mathrm{R}$ receptors, which signal through the $\mathrm{G}_{\alpha \mathrm{\alpha i} 2}$ subunit of trimeric $\mathrm{G}$ proteins. In contrast, sensory neurons located in the basal region express V2Rs, which signal through the $G_{\alpha o}$ subunit (Jia and Halpern, 1996). The segregation of VSN cell bodies observed within the VNO is maintained among their axonal projections within their target field, the accessory olfactory bulb (AOB). Neurons located in the apical region of the $\mathrm{VNO}$ innervate glomeruli within the anterior half of the $\mathrm{AOB}$, while neurons located in the basal region of the VNO project their axons to the posterior half of the $\mathrm{AOB}$ (Halpern et al., 1995, 1998; Jia and Halpern, 1996).

Several families of axon guidance cues have been implicated in regulating the development of vomeronasal projections. The Ephrin family member, Ephrin A5, is expressed on axons of apical VNO neurons and is required for their targeting to the anterior region of the $\mathrm{AOB}$, presumably through attractive interactions with EphA6 receptors expressed in mitral cells of the AOB (Knöll et al., 2001). In addition, repulsive forces are also involved in the targeting of this population of axons. The secreted semaphorin receptor Npn-2 is required for the fasciculation and segregation of apical VSN axons to the anterior region of the $\mathrm{AOB}$ (Cloutier et al., 2002; Walz et al., 2002). The Npn-2-dependent fasciculation and targeting of subsets of V1R-expressing axons is 
regulated in part by the secreted semaphorin Sema3F (Cloutier et al., 2004; Walz et al., 2007).

Another secreted chemorepellent, Slit-1, has been implicated in directing the targeting of basal VSN axons. Ablation of Slit-1 expression leads to mistargeting of a subset of V2R-expressing vomeronasal axons to the anterior region of the AOB (Cloutier et al., 2004). However, the Slit receptor that modulates Slit-1-dependent targeting of basal VSN axons has yet to be defined. Herein we have examined the role of the Slit receptors, Robo-1 and Robo-2, in the development of accessory olfactory projections by ablating their expression in mice. Our results show that, while Robo-1 is dispensable for the segregation of VSN axons in the AOB, expression of Robo-2 in VSNs is essential for accurate targeting of basal VSN axons to the posterior region of the AOB.

\section{Materials and Methods}

Animals. For in situ hybridization experiments, embryonic day (E) E14, E16, and E18 embryos, and postnatal day (P) P0 and P5 mice were obtained from timed-pregnant $\mathrm{CD} 1$ and C57BL6 females purchased from Charles River. Date of vaginal plug was considered as E0. Similar patterns of expression for slit and Robo family members were observed in both mouse strains. Robo-1 (Andrews et al., 2008), Robo-2 (Grieshammer et al., 2004), floxed Robo-2 (Lu et al., 2007), slit-1 (Plump et al., 2002), slit-2 (Plump et al., 2002), and slit-3 (Yuan et al., 2003) mutant mice have been described. Nestin-Cre (Tronche et al., 1999), VN12-tau-lacZ (Belluscio et al., 1999), EC2tau-lacZ (Cloutier et al., 2004), and OMP-Cre (Eggan et al., 2004) have also been described.

Generation of Robo-1 antibody. Anti-Robo-1 antibodies were produced by immunizing rabbits with a synthetic peptide from the C-terminal region of Robo-1 (CFERGDENNEELETES) coupled to keyhole limpet hemocyanin. Rabbits were immunized with $250 \mu \mathrm{g}$ of coupled peptide in complete Freunds adjuvant and boosted every 2-3 weeks with $100 \mu \mathrm{g}$ of coupled peptide. Serum was collected and the specificity of the serum for Robo-1 was determined by immunoblot analysis using extracts of Robo-1- or Robo-2-transfected 293T cells (data not shown) and by immunostaining on sections of olfactory bulbs from adult wildtype and robo- $1^{-1-}$ mice (see Fig. $1 K, L$ ).

In situ hybridization. Nonradioactive, dioxygenin-labeled cRNA probes with either sense or antisense orientation were synthesized by in vitro transcription using DIG labeling mix (Roche) according to the manufacturer's recommendations. Probes were synthesized from cDNA clones encoding robo-1 and robo-2 (Brose et al., 1999), rig-1 (Cho et al., 2007), slit-1, slit-2 and slit-3 (Yuan et al., 1999) and $G_{\alpha i 2}$ and $G_{\alpha o}$ (Cloutier et al., 2002). An additional slit-3 probe was also used to confirm the results obtained (Marillat et al., 2002). For in situ hybridization on E14, E16, and E18 embryos, as well as on P0 and P15 mice, fresh frozen brains or nasal cavities were cryosectioned at $20 \mu \mathrm{m}$, fixed, and processed as previously described (Cloutier et al., 2002).
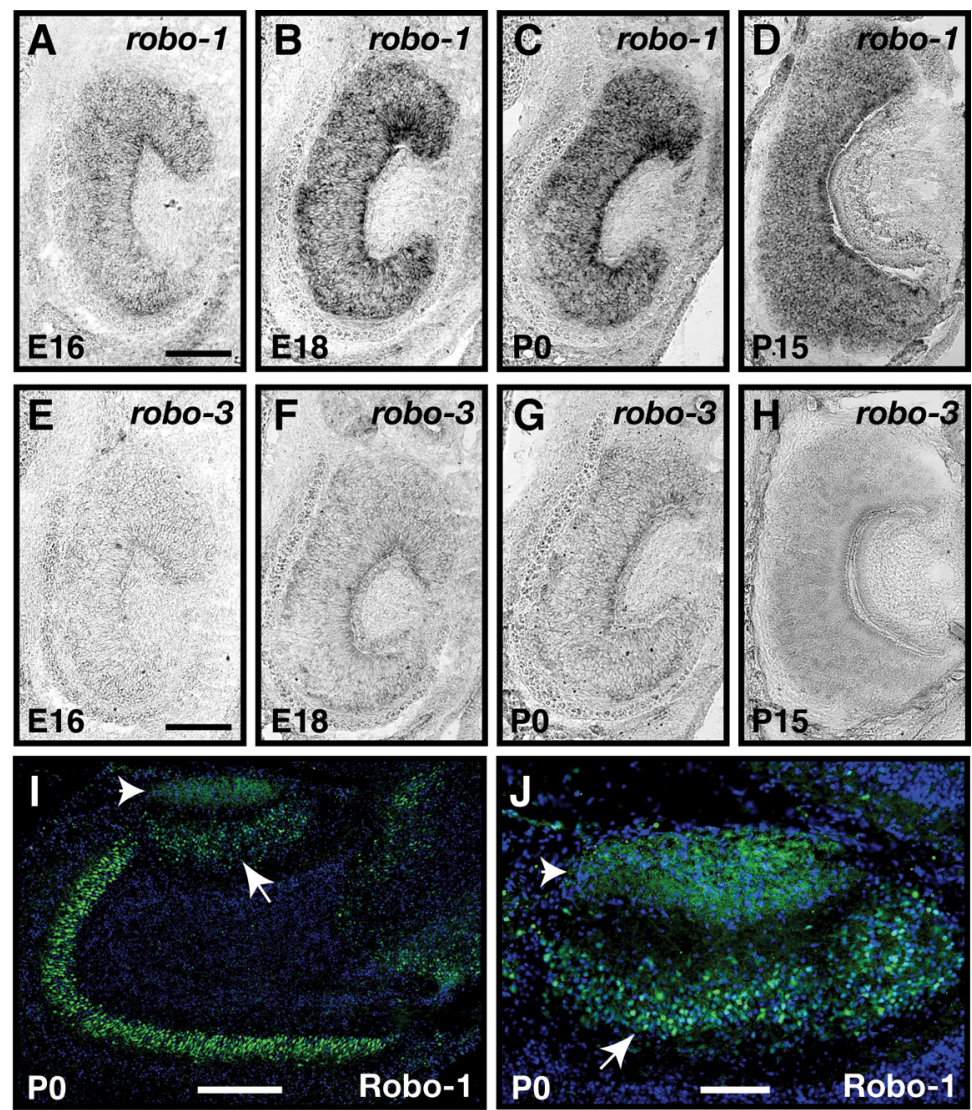

robo- $1^{+/}$
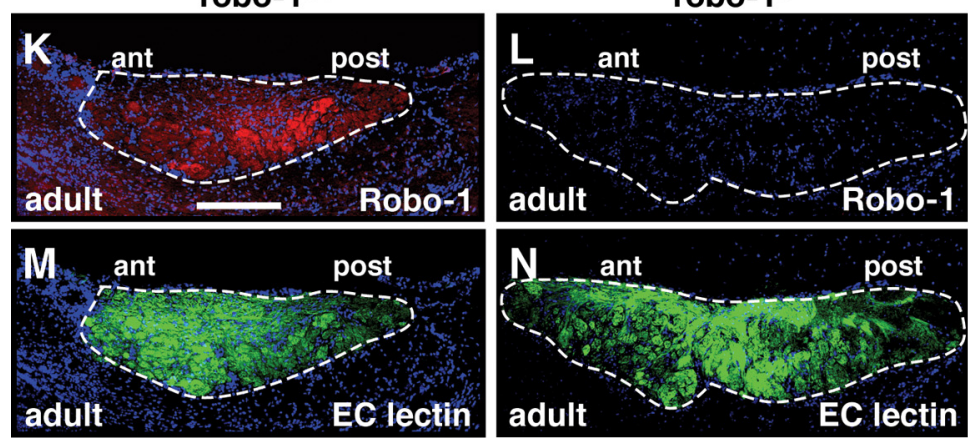

Figure 1. Expression of Robo- 1 in vomeronasal sensory neurons. $\boldsymbol{A}-\boldsymbol{H}$, In situ hybridization of coronal sections of vomeronasal organ isolated from $\mathrm{E} 16(\boldsymbol{A}, \boldsymbol{E}), \mathrm{E} 18(\boldsymbol{B}, \boldsymbol{F}), \mathrm{PO}(\boldsymbol{C}, \boldsymbol{G})$, and $\mathrm{P} 15$ mice $(\boldsymbol{D}, \boldsymbol{H})$ with DIG labeled cRNA probes specific for robo- $1(\boldsymbol{A}-\boldsymbol{D})$ or robo-3 $(\boldsymbol{E}-\boldsymbol{H})$. From E16 to P15, low levels of robo-1 transcripts are detected in vomeronasal sensory neurons. In contrast, robo-3 is not detected in vomeronasal sensory neurons at these developmental stages. Scale bars, $250 \mu \mathrm{m}$. I-N, Sagittal sections of the accessory olfactory bulb from PO $(\boldsymbol{I}, \boldsymbol{J})$ and adult $(\boldsymbol{K}-\boldsymbol{N})$ mice stained with Robo-1 antibodies $(\boldsymbol{I}-\boldsymbol{L}), \mathrm{EC}$ lectin $(\boldsymbol{M}, \boldsymbol{N})$, and Hoechst accessory olfactory bulb $(I, J)$ at P0. Robo- 1 is also detected in the nerve and glomerular layers of the accessory olfactory bulb in dult wild-type mice but not in robo- $1^{-/-}$mice $(\boldsymbol{K}, \boldsymbol{L})$. Dotted lines outline the nerve and glomerular layers of the AOB in $\boldsymbol{K}-\boldsymbol{N}$. Scale bars: $125 \mu \mathrm{m}(\boldsymbol{I}, \boldsymbol{K}-\boldsymbol{N}) ; 50 \mu \mathrm{m}(\boldsymbol{J})$.

Immunohistochemical procedures. Adult mice were anesthetized and perfused transcardially with ice-cold PBS containing $4 \%$ paraformaldehyde. Brains were dissected, postfixed for 5-10 min in perfusion solution, and cryoprotected in PBS containing 30\% sucrose. Alternatively, embryos and P0 mouse heads were immersion-fixed in PBS containing 4\% paraformaldehyde followed by cryoprotection in PBS containing 30\% sucrose. The samples were cryosectioned $(20 \mu \mathrm{m})$, mounted on Superfrost plus microscope slides and allowed to dry for $1 \mathrm{~h}$. The sections were rinsed twice in TBS (50 mM Tris- $\mathrm{HCl}[\mathrm{pH} 7.6]$ and $150 \mathrm{~mm} \mathrm{NaCl}$ ) and blocked for $2 \mathrm{~h}$ in TNT (50 mm Tris- $\mathrm{HCl}$ [pH 7.6], $500 \mathrm{~mm} \mathrm{NaCl}$, and $0.5 \%$ Triton X-100) containing $10 \%$ fetal bovine serum (FBS). The sections were then incubated overnight with primary antibody at $4^{\circ} \mathrm{C}$ in 

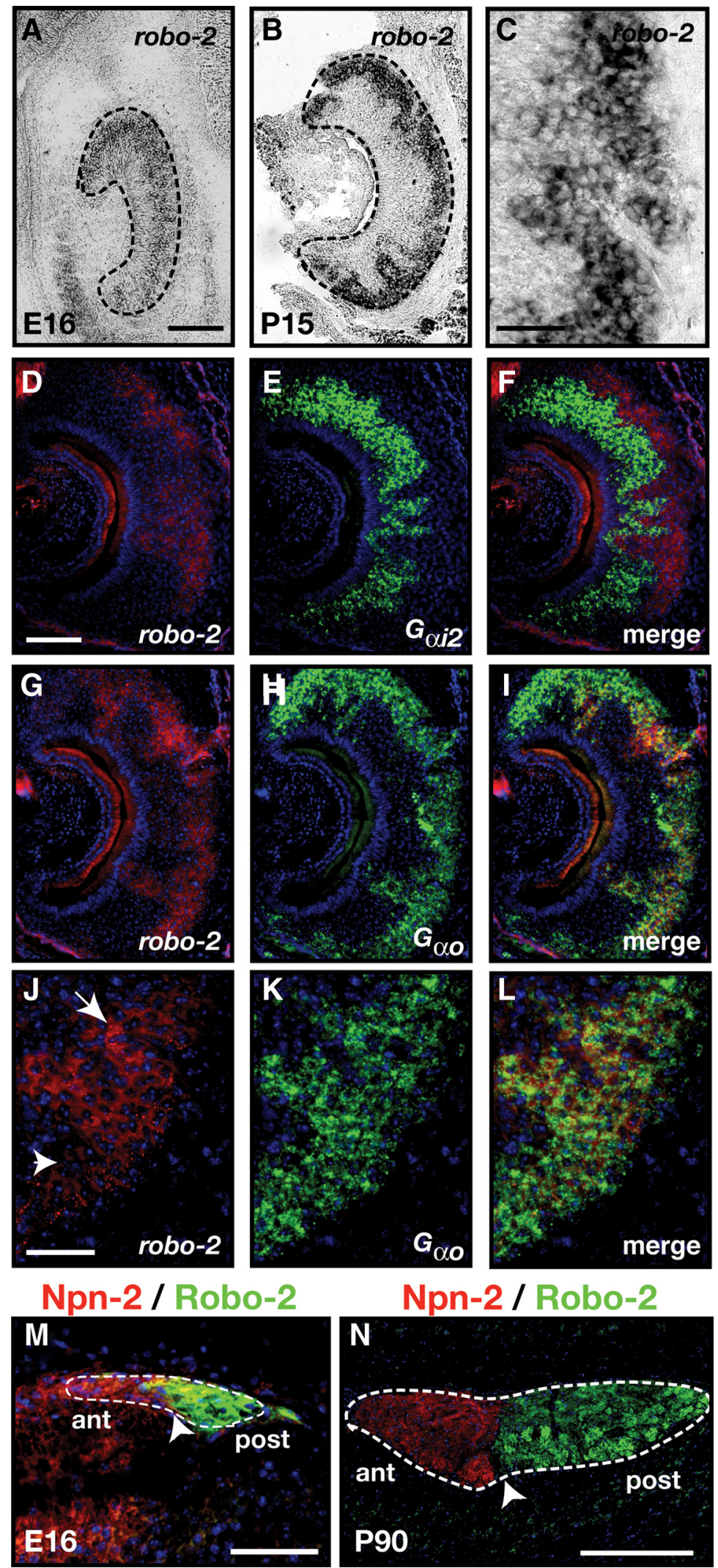

Figure 2. Expression of Robo-2 in vomeronasal sensory neurons. $\boldsymbol{A}-\boldsymbol{L}$, In situ hybridization of coronal sections of vomeronasal organ isolated from an E16 embryo $(\boldsymbol{A})$ and P15 mice $(\boldsymbol{B}-\boldsymbol{L})$ with DIG-labeled cRNA probes specific for robo-2 $(\boldsymbol{A}-\boldsymbol{D}, \boldsymbol{F}, \mathbf{G}, \boldsymbol{I}, \boldsymbol{J}, \boldsymbol{L})$ and fluorescein-labeled CRNA probes specific for $G \alpha_{i 2}(\boldsymbol{E}, \boldsymbol{F})$ and $G_{\alpha o}(\boldsymbol{H}, \boldsymbol{I}, \boldsymbol{K}, \boldsymbol{L})$. At E16, robo-2 is expressed in vomeronasal neurons while robo-2 expression becomes restricted to vomeronasal neurons located in the basal region of the VN0 postnatally $(\boldsymbol{B}, \boldsymbol{C})$. Robo-2 is not expressed in the $G \alpha_{\mathrm{i} 2}$-expressing vomeronasal neuron population $(\boldsymbol{D}-\boldsymbol{F})$ while all $G_{\alpha o}$ vomeronasal neurons express robo-2 (G-L). High-magnification image of vomeronasal neurons coexpressing $G_{\alpha o}$ and robo-2 reveal that $G_{\alpha o}$-positive neurons express high (arrow) or low (arrowhead) levels of robo-2 (J-L). Dotted lines outline the VN0 (A, $\boldsymbol{B})$. Scale bars: $250 \mu \mathrm{m}$
TNT/10\% FBS using the following dilutions: anti-Npn-2 (1:500; BD Biosciences), antiRNCAM/OCAM (1:500; Transduction Laboratories), anti- $\beta$ III tubulin (1:6000; Promega), anti- $G_{\alpha \mathrm{i}}$ (1:500; WAKO Chemicals), anti- $G_{\alpha \mathrm{o}}$ (1:500; MBL), anti-GFP (1:500; Invitrogen), anti- $\beta$-galactosidase (1:500; Abd Serotech), anti-Robo-1 (1:500), and anti-Robo-2 (1:350) (Cho et al., 2007). After rinsing in TBS, primary antibody was detected with the appropriate Alexa-488 or Alexa-546-conjugated secondary antibody (1:500; Invitrogen) in TNT/10\% FBS. Erythrina Cristagalli (EC) lectin (1:500; Vector Laboratories) and Banderiraea Simplicifolia (BS) lectin (1:1500; Vector Laboratories) were applied with the secondary antibody.

Analysis of the segregation of $\beta$-galactosidaseand $G_{\alpha o}$-positive glomeruli in adult accessory olfactory bulbs. Two- to three-month-old adult mice were perfused as described above. Both olfactory bulbs were cryosectioned $(20 \mu \mathrm{m})$ in the sagittal plane and all sections were collected on microscope slides. Sections were immunostained with $\beta$-galactosidase antibodies, incubated with BS lectin, and counter-stained with Hoescht. The border between the anterior and posterior regions of the $\mathrm{AOB}$ was identified by the intensity of BS lectin as previously described (Tanaka et al., 1999; Cloutier et al., 2002). The number of ectopic $\beta$-galactosidase-positive projections observed in the anterior region of the AOB were counted on each section of both AOBs from each mouse examined. Ectopic $\beta$-galactosidase-positive glomeruli were defined by the termination of a distinguishable $\beta$-galactosidase-expressing fiber by a bulbar mass in the glomerulus or by the agglomeration of several $\beta$-galactosidase-expressing fibers in a region containing multiple glomeruli.

To obtain an approximate measure of the percentage of $\mathrm{G}_{\alpha \mathrm{o}}$-positive axons that innervate the anterior region of the $\mathrm{AOB}$ in robo- $2^{\text {lox/lox}}$; Nestin-Cre; and robo-2 $2^{\text {lox/lox}}$; OMP-Cre mice, the fluorescence intensity of $\mathrm{G}_{\alpha o}$-positive axons observed in the anterior region of the $\mathrm{AOB}$ was compared to the fluorescence intensity of $\mathrm{G}_{\alpha \mathrm{o}}$-positive axons observed in the posterior region of the AOB.

$X$-Gal staining. For whole-mount X-Gal staining, 2- to 3-month-old adult mice were perfused transcardially with ice-cold PBS containing 4\% paraformaldehyde, $2 \mathrm{~mm} \mathrm{MgSO}_{4}$, and $5 \mathrm{~mm}$ EGTA. Whole olfactory bulbs were processed for X-Gal staining as previously described (Mombaerts et al., 1996).

$(\boldsymbol{A}, \boldsymbol{B}, \boldsymbol{D}-\boldsymbol{I}) ; 125 \mu \mathrm{m}(\boldsymbol{C}, \boldsymbol{J}-\boldsymbol{L}) . \boldsymbol{M}, \boldsymbol{N}$, Sagittal sections of the accessory olfactory bulb from an E16 embryo $(M)$ and an adult $(\boldsymbol{N})$ mouse stained with Robo-2 and Neuropilin-2 antibodies. Robo-2 expression is observed exclusively in axons innervating the posterior region of the $A 0 B$ while Neuropilin-2 expression is restricted to axons innervating the anterior $A O B$ (Cloutier et al., 2002). Dotted lines outline the AOB while arrowheads denote the border between Neuropilin-2 and Robo-2 staining. Scale bars: $50 \mu \mathrm{m}(\boldsymbol{M}) ; 250 \mu \mathrm{m}(\boldsymbol{N})$. 


\section{Results}

To begin to assess the involvement of Robo family members in the development of vomeronasal projections, we examined their patterns of expression by in situ hybridization during embryogenesis when vomeronasal axons begin to segregate in the anterior and posterior regions of the AOB. Consistent with previous reports, robo-1 and robo-2 transcripts were detected in VSNs. Low levels of robo-1 transcripts were observed in VSNs at E16, E18, P0, and P15 (Fig. 1A-D). Examination of Robo-1 protein expression on vomeronasal axons revealed that Robo-1-expressing VSNs project their axons to both the anterior and posterior regions of the $\mathrm{AOB}$ at $\mathrm{P} 0$ and in the adult, indicating that Robo-1 is expressed by both apical and basal VSNs. Slightly higher levels of Robo-1 protein were observed on basal VSN axons in the adult. In contrast to robo-1, robo-2 is expressed at high levels in a subset of VSNs at E16 and its expression becomes restricted to $\mathrm{G}_{\alpha \mathrm{o}}$-expressing VSNs located in the basal region of the VNO by P15 (Fig. 2A-C,G,I) (Knöll et al., 2003; Cloutier et al., 2004). Interestingly, heterogenous levels of robo-2 transcripts are observed in basal VSNs with some neurons expressing lower levels of robo-2 (Fig. 2C,J). Examination of Robo-2 protein expression on vomeronasal axons by immunohistochemistry revealed that Robo-2expressing VSNs project their axons to the posterior region of the AOB. The segregation of Robo-2-positive axons to the posterior region is observed as early as E16 and is maintained into adulthood (Fig. 2M,N). In contrast to robo-1 and robo-2, robo-3, also known as rig-1, is not expressed in VSNs (Fig. $1 E-H$ ).

The expression of Robo-1 and Robo-2 in VSNs suggests that their axons may respond to Slits expressed in the AOB (Knöll et al., 2003; Marillat et al., 2002). We examined the expression of Slit family members in the AOB at E14, E16, E18, and P0, when vomeronasal axons innervate the AOB. In situ hybridization revealed that slit-1 is highly expressed in a subset of cells located at the most anterior tip of the developing $\mathrm{AOB}$ (Fig. $3 A, D, G, J$ ) while slit-2 is expressed at low levels throughout the mitral cell layer of the AOB at all ages examined (Fig. $3 B, E, H, K$ ). Since low levels of slit-2 transcripts were detected by in situ hybridization, we confirmed its expression in the AOB using anti-GFP immunostaining on Slit-2-GFP mice (Plump et al., 2002). GFP signal is observed in the mitral cell layer and nerve layer of the AOB in these mice (Fig. 3O). Similar patterns of expression for slit-1 and slit-2 in the AOB of P0 mice have been previously described (Knöll et al., 2003). In contrast to slit-1 and slit-2, slit-3 expression is observed in the posterior region of the AOB at E14 and E16 and becomes re-

E16

E18

PO slit-1

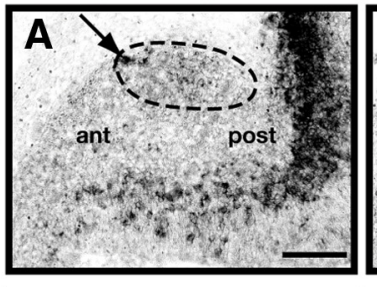

Expression of slits in the $A O B$. $A-N$, In situ hybridization of sagittal sections of the accessory olfactory bulb of $E 14$ E16 (D-F), E18 (G-I), and P0 (J-N) mice with cRNA probes specific for slit-1 $(\boldsymbol{A}, \boldsymbol{D}, \boldsymbol{G}, \boldsymbol{J})$, slit-2 $(\boldsymbol{B}, \boldsymbol{E}, \boldsymbol{H}, \boldsymbol{K})$, and slit-3 $(\boldsymbol{C}, \boldsymbol{F}$, accessory olfactory bulb of $\mathrm{PO}$ slit- $3^{+/+}(\boldsymbol{M})$ and slit-3 ${ }^{-/-}(\boldsymbol{M})$ littermates was performed to assess the specificity of the slit-3 RNA probe. Slit-3 expression is not detected in the slit- $3^{-1-}$ mouse demonstrating specificity of the cRNA probe used. Dotted accessory olfactory bulb of an E18 slit-2 $2^{+/-}$embryo. The signal detected in the mitral cell layer of the accessory olfactory bulb confirms the expression of slit-2 observed by in situ hybridization. Scale bars, $50 \mu \mathrm{m}$.
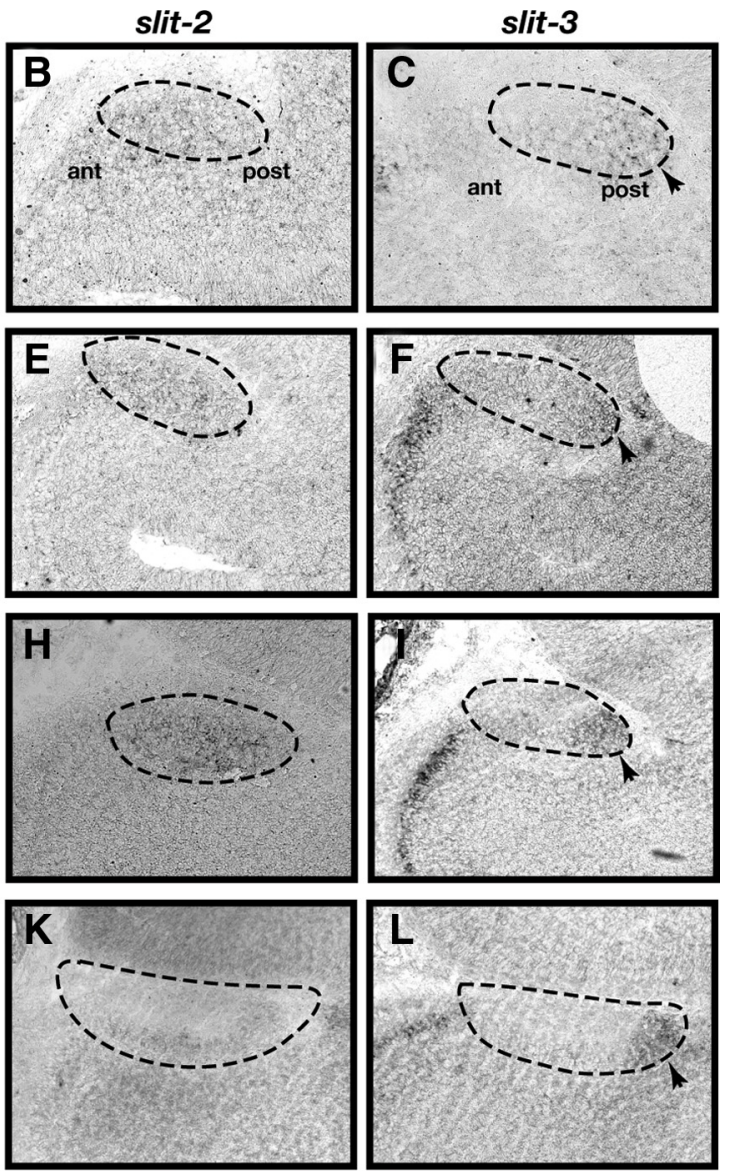

GFP
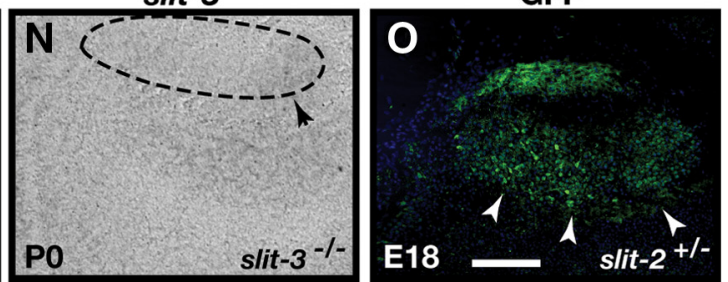

stricted to mitral cells located in the most posterior part of the AOB by E18 and P0 (Fig. 3C, F, I,L). Since it has previously been reported that slit-3 is expressed in a similar pattern as slit-1 in the AOB by in situ hybridization (Knöll et al., 2003), we confirmed our result by examining slit-3 expression using a second previously characterized cRNA probe (Marillat et al., 2002). Using this probe, slit-3 expression was also observed in the posterior region of the AOB from E16 to P1 (Fig. 3M) (data not shown). The signal detected in the posterior region of the AOB was not observed in AOB sections from slit- $3^{-1-}$ mice indicating that our probe detects specifically slit-3 transcripts (Fig. $3 N$ ). Interestingly, a similar pattern of expression for all slit family members in the AOB is observed in postnatal mice and may therefore con- 

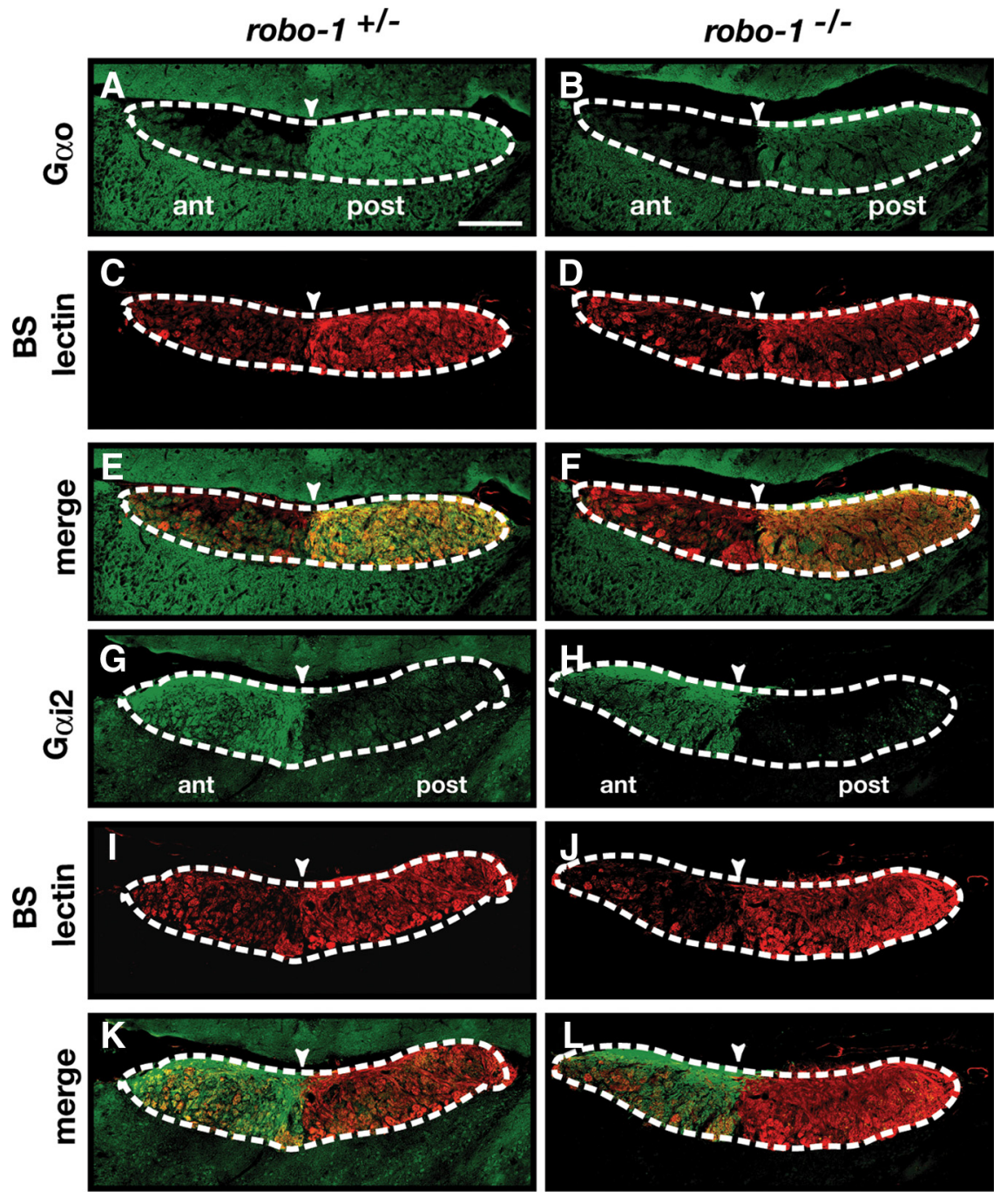

Figure 4. The segregation of basal and apical vomeronasal neuron axons in the accessory olfactory bulb is unaffected in robo- $1^{-/-}$mice. $A-L$, Parasagittal AOB sections of adult robo- $1^{+/-}(A, C, E, G, I, K)$ and robo- $1^{-/-}(B, D, F, H, J, L)$ mice were stained with $G \alpha_{0}$ antibodies $(\boldsymbol{A}, \boldsymbol{B}, \boldsymbol{E}, \boldsymbol{F})$, BS lectin $(\boldsymbol{C}-\boldsymbol{F}, \boldsymbol{I}-\boldsymbol{L})$, and $G \alpha_{\mathrm{i} 2}$ antibodies $(\boldsymbol{G}, \boldsymbol{H}, \boldsymbol{K}, \boldsymbol{L})$. Projections of $G \alpha_{0}$-expressing basal vomeronasal neurons and $G \alpha_{i 2}$-expressing apical vomeronasal neurons are restricted to the posterior and anterior regions of the $A 0 B$, respectively, in both robo- $1^{+/-}(A, E, G, K)(n=3)$ and robo- $1^{-1-}(B, F, H, L)(n=6)$ mice. Dotted lines outline the nerve and glomerular layers of the $\mathrm{AOB}$, and arrowheads indicate the anterior-posterior border as defined by BS lectin staining. Scale bar, $125 \mu \mathrm{m}$.

tribute to the targeting of axons to the $\mathrm{AOB}$ at later time points during development.

Ablation of Robo-2 expression leads to mistargeting of some basal VSN axons in the anterior region of the AOB

The expression of Robo-1 and Robo-2 in VSN suggested they could contribute to the targeting of projecting VSN axons in the AOB. To determine whether these two Slit receptors are required for the segregation of VSN axons into the anterior and posterior regions of the AOB, we examined the effect of a loss of Robo-1 or Robo-2 expression on vomeronasal projections.

Sections of AOB from robo- $1^{+/-}$and robo- $1^{-/-}$mice were stained with anti- $G_{\alpha \mathrm{i} 2}$ or anti- $\mathrm{G}_{\alpha \mathrm{o}}$ to visualize axons projecting from the apical and basal VSNs, respectively. Sections were costained with BS lectin to identify the anterior-posterior border of the AOB. As observed in robo- $1^{+/-}$and wild-type mice, $\mathrm{G}_{\alpha_{0}}{ }^{-}$ expressing axons project exclusively to the posterior half of the $\mathrm{AOB}$ in robo- $1^{-/-}$mice (Fig. $4 A, B, E, F$ ). Apical VSN axons ex- pressing $\mathrm{G}_{\alpha \mathrm{i} 2}$ also segregate properly to the anterior region of the $\mathrm{AOB}$ in robo$1^{-/-}$mice (Fig. $4 H, L$ ). These results demonstrate that expression of Robo-1 is not required for the accurate segregation of VSNs axons into the AOB.

The perinatal death of robo- $2^{-/-}$mice precluded us from evaluating the accuracy of projections to the $\mathrm{AOB}$ in these mice due to the small size of the AOB at that age. Therefore, we generated robo-2 conditional mice expressing Cre recombinase under the control of the Nestin promoter to ablate expression of Robo-2 in all neurons (Tronche et al., 1999). The majority of robo-2 $2^{\text {lox/lox }}$; Nestin-Cre mice die early after birth but a subset of animals survive to adulthood which allowed us to examine the accuracy of VSN projections to the AOB. Immunostaining of coronal sections of the VNO with anti-Robo-2 revealed that Robo-2 expression is ablated from axons of VSNs early during development of these projections (E14) in robo$2^{\text {lox/lox}}$; Nestin-Cre mice (Fig. $5 A^{\prime}, B^{\prime}$ ). Sections of AOB from robo- $2^{+/ \text {lox }}$; NestinCre and robo- $2^{\text {lox/lox }}$; Nestin-Cre mice were stained with anti- $\mathrm{G}_{\alpha \mathrm{o}}$ to visualize axons projecting from the basal VSNs and with BS lectin to identify the anterior-posterior border of the AOB. While $G_{\alpha_{0}}$ expressing axons project exclusively to the posterior half of the AOB in robo- $2^{+/ l o x}$; Nestin-Cre mice, a population of fibers was found to innervate the anterior half of the $\mathrm{AOB}$ in all robo-2 $2^{\text {lox/lox}}$; Nestin-Cre mice analyzed (Fig. 6B, F). A semiquantitative assessment of the mistargeted axons revealed that $\sim 28 \%$ of basal VSN axons innervate the anterior region of the $\mathrm{AOB}$ in robo- $2^{\text {lox/lox}}$; Nestin-Cre. In contrast, apical VSN axons expressing $\mathrm{G}_{\alpha \mathrm{i} 2}$ segregate properly to the anterior region of the AOB in robo-2 $2^{\text {lox/lox }}$; Nestin-Cre mice (Fig. $6 H, L$ ).

To better define the role of Robo- 2 in the segregation of vomeronasal projections, we generated robo-2 $2^{\text {lox/lox }}$; Nestin-Cre mice that express tau-lacZ in a specific subpopulation of basal VSNs expressing the EC2 vomeronasal receptor. Whole-mount X-Gal staining on AOBs from these mice allowed us to visualize AOB targeting by this specific subset of axons. In all robo-2 $2^{+/ l o x}$; NestinCre mice analyzed, lacZ-positive fibers were targeted to the posterior region of the $\mathrm{AOB}$ (Fig. $6 \mathrm{M}$ ). In contrast, some lacZpositive axons innervate the anterior region of the $\mathrm{AOB}$ in all robo-2 $2^{\text {lox/lox }}$; Nestin-Cre mice analyzed (Fig. $6 \mathrm{~N}$ ).

Since Robo- 2 has previously been implicated in the regulation of axonal fasciculation (Fouquet et al., 2007; Plachez et al., 2008), we next examined the integrity of the vomeronasal tract in robo$2^{\text {lox/lox}}$; Nestin-Cre mice. Coronal sections of the olfactory bulb were stained with EC lectin to visualize all VSN axons projecting to the AOB (Cloutier et al., 2004). In robo- $2^{+/ l o x} ;$ Nestin-Cre and robo-2 $2^{\text {lox/lox }}$; Nestin-Cre mice, these axons are tightly fasciculated and form large bundles which course along the medial surface of 

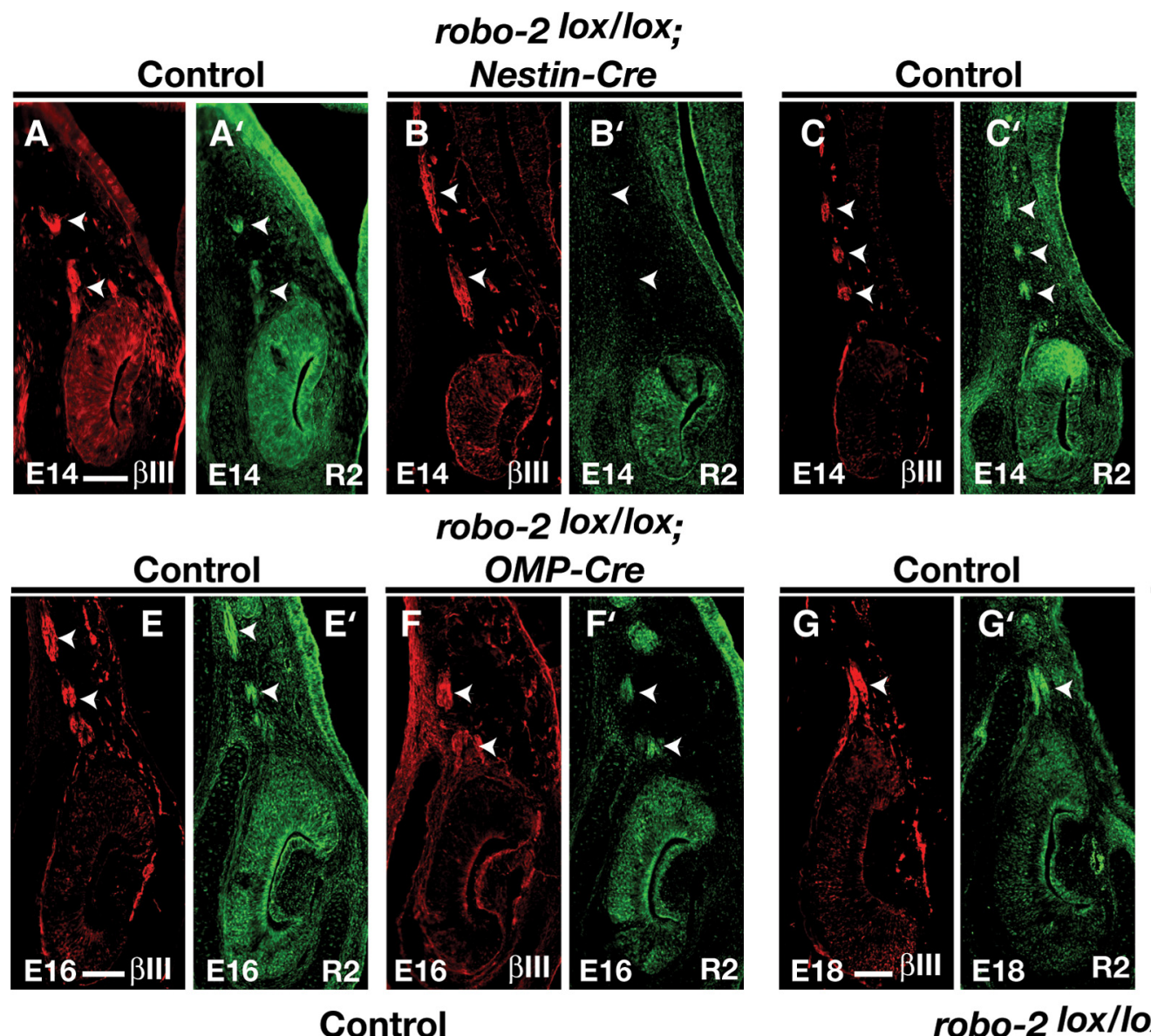

robo-2 lox/lox;

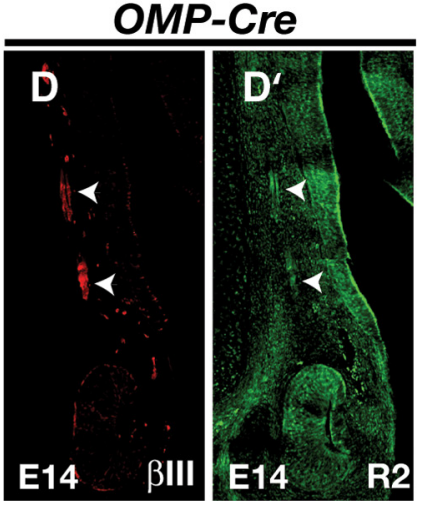

robo-2 lox/lox;

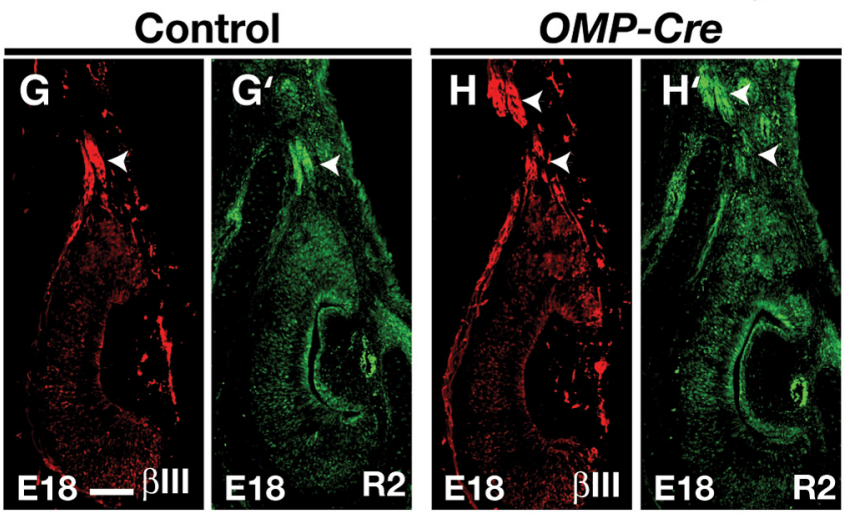

Control
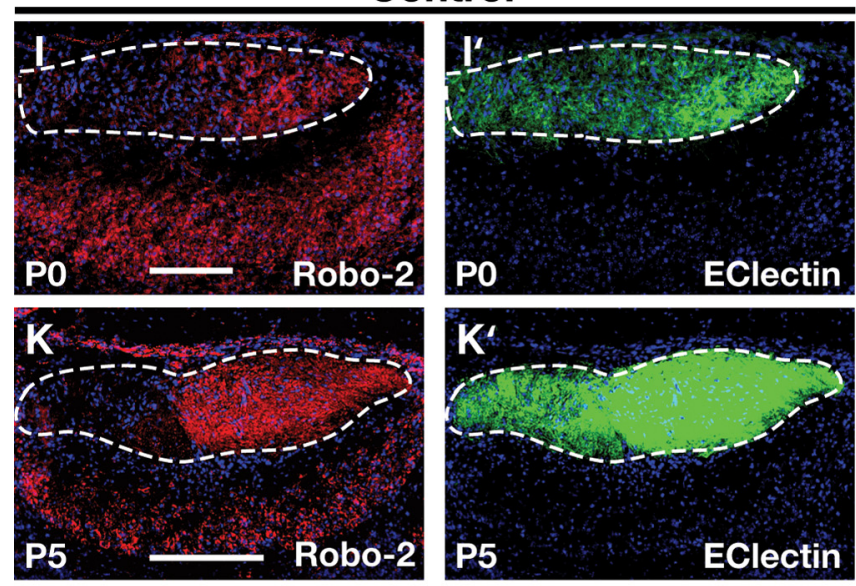

robo-2 lox/lox; OMP-Cre
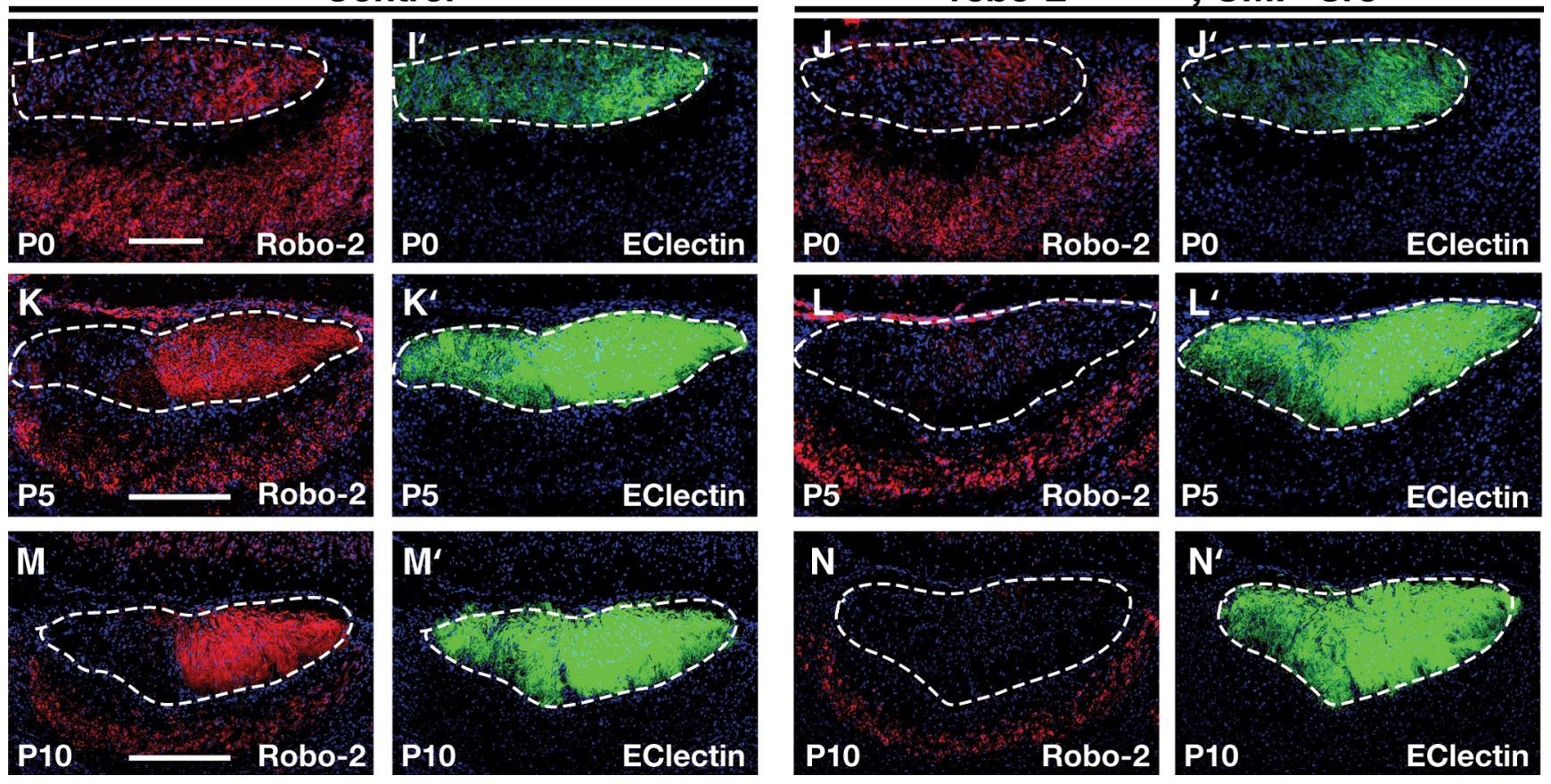

Figure 5. Time course of Robo-2 ablation on vomeronasal axons of robo-2 $2^{10 x / 10 x}$; Nestin-Cre and robo-2 $2^{10 x / 10 x} ; 0 \mathrm{MP}-$ Cre mice. $\boldsymbol{A}-\boldsymbol{H}^{\prime}$, Immunohistochemistry of coronal sections of the VNO from E14

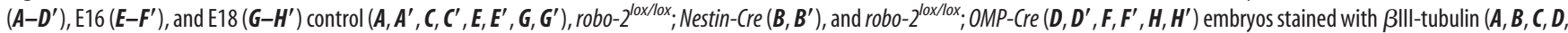
$\boldsymbol{E}, \boldsymbol{F}, \boldsymbol{G}, \boldsymbol{H})$ or Robo-2 $\left(\boldsymbol{A}^{\prime}, \boldsymbol{B}^{\prime}, \boldsymbol{C}^{\prime}, \boldsymbol{D}^{\prime}, \boldsymbol{E}^{\prime}, \boldsymbol{F}^{\prime}, \boldsymbol{G}^{\prime}, \boldsymbol{H}^{\prime}\right)$ antibodies. Robo-2 staining is not detected on vomeronasal axons at $\mathrm{E} 14$ in robo- $2^{\text {lox/lox }}$; Nestin-Cre mice $\left(\boldsymbol{B}^{\prime}\right)$ but is highly expressed on vomeronasal axons of robo-2 $2^{\text {lox/lox; }}$ OMP-Cre mice from E14 to E18 $\left(\boldsymbol{D}^{\prime}, \boldsymbol{F}^{\prime}, \boldsymbol{H}^{\prime}\right)$. Arrowheads indicate vomeronasal axons. Immunostaining was performed on three different robo-2 ${ }^{\text {lox/lox}} ;$ Nestin-Cre or OMP-Cre embryos and three control littermates at each developmental stage. Control littermates included robo- $2^{+/ 10 x}$; Nestin/OMP-Cre, robo- $2^{\text {lox/lox }}$, and robo-2 $2^{+/ 10 x}$ embryos. Scale bar, $60 \mu \mathrm{m}$. I-N' Immunohistochemistry of sagittal sections of the accessory olfactory bulb from P0 $\left(I-J^{\prime}\right)$, P5 $\left(K-L^{\prime}\right)$, and P10 $\left(M-N^{\prime}\right)$ control $\left(I, I^{\prime}, K, K^{\prime}, M, M^{\prime}\right)$ or robo-2 ${ }^{l o x / l o x} ;$ OMP-Cre $\left(J, J^{\prime}, L, L^{\prime}, N, N^{\prime}\right)$ mice stained with Robo-2 antibodies $(I, J, K, L, M, M)$ or EC lectin $\left(I^{\prime}, J^{\prime}, K^{\prime}, L^{\prime}, M^{\prime}, N^{\prime}\right)$. Robo-2 staining is decreased on vomeronasal axons at P0 and is completely ablated by P10 in robo-2 ${ }^{l o x / 10 x} ; 0 M P$-Cre mice $(J, L, M)$. Dotted lines outline the nerve and glomerular layers of the AOB. Immunostaining was performed on three differentrobo-2 ${ }^{\text {lox/lox}}$; Nestin-Cre or OMP-Cremice and three control littermates at each developmental stage. Control littermates included robo-2 $2^{+/ 10 x} ;$ Nestin/OMP-Cre, robo-2 $2^{\text {lox/lox }}$, and robo-2 $2^{+/ 10 x}$ mice. Dotted lines outline the AOB. Scale bars: $100 \mu \mathrm{m}\left(\boldsymbol{I}-\boldsymbol{J}^{\prime}\right) ; 250 \mu \mathrm{m}\left(\boldsymbol{K}-\boldsymbol{N}^{\prime}\right)$. 


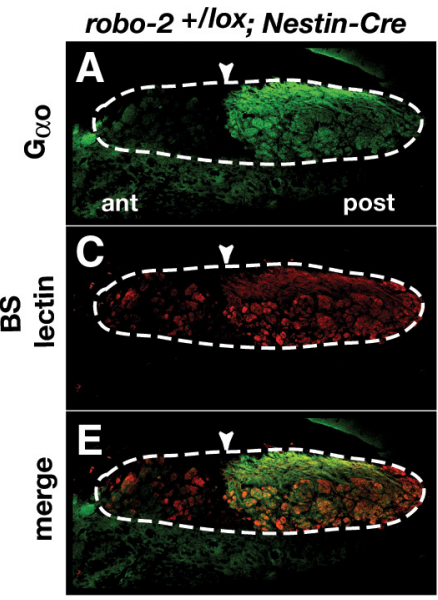

robo-2 lox/lox; Nestin-Cre
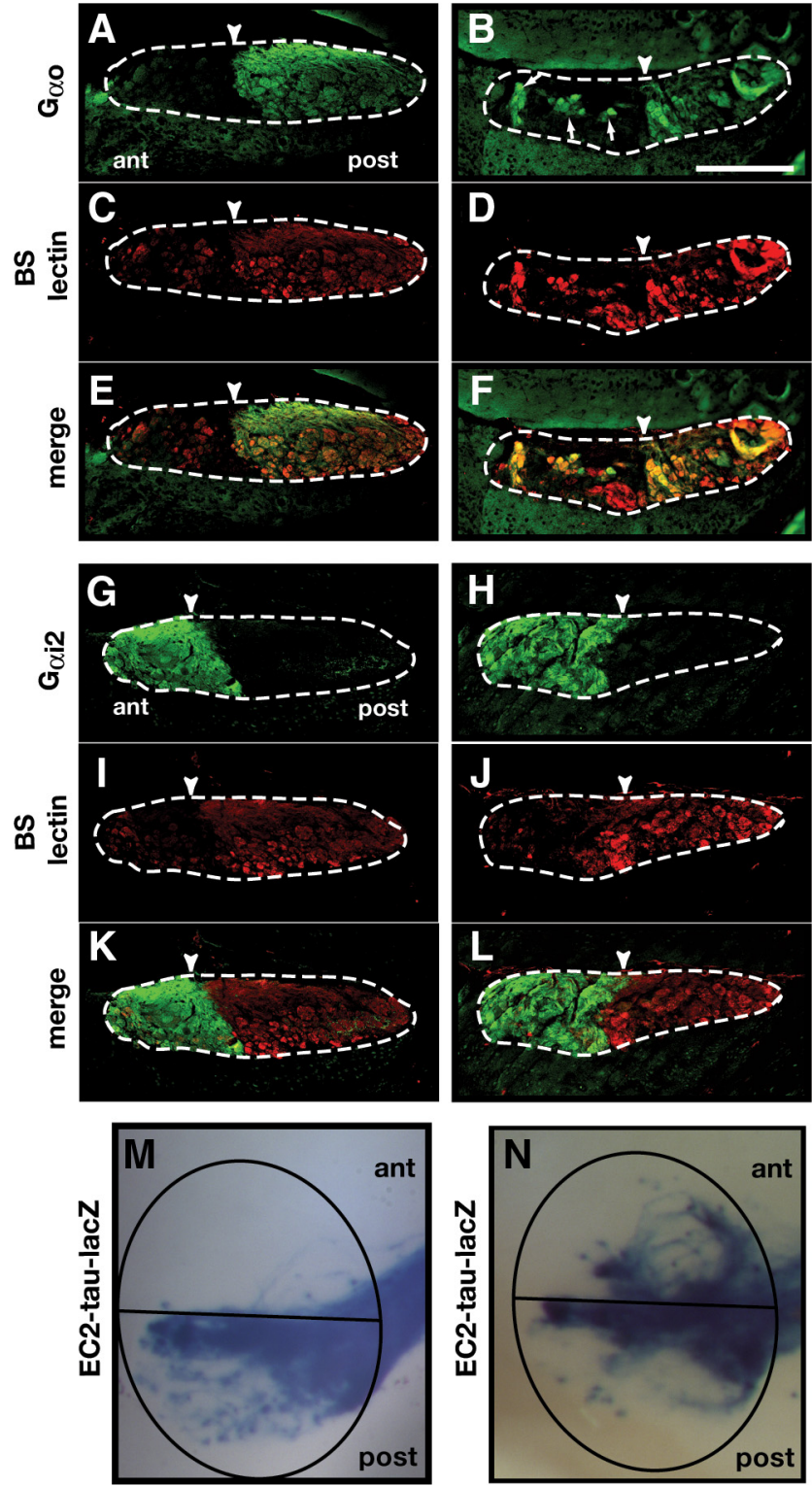

Figure 6. Subsets of basal vomeronasal projections show loss of zonal segregation within the accessory olfactory bulb of robo- $2^{\text {lox/lox; }}$; Nestin-Cre mice. $A-L$, Parasagittal AOB sections of adult robo-2 $2^{+/ l o x} ;$ Nestin-Cre $(\boldsymbol{A}, \boldsymbol{C}, \boldsymbol{E}, \boldsymbol{G}, \boldsymbol{I}, \boldsymbol{K})$ and robo-2 $2^{\text {lox/lox}} ;$ Nestin-Cre $(\boldsymbol{B}, \boldsymbol{D}, \boldsymbol{F}, \boldsymbol{H}, \boldsymbol{J}, \boldsymbol{L})$ mice were stained with $G \alpha_{0}$ antibodies $(\boldsymbol{A}, \boldsymbol{B}, \boldsymbol{E}, \boldsymbol{F})$, BS lectin $(\boldsymbol{C}-\boldsymbol{F}, \boldsymbol{I}-\boldsymbol{L})$, and $\mathrm{G} \alpha_{\mathrm{i}}$ antibodies $(\boldsymbol{G}, \boldsymbol{H}, \boldsymbol{K}, \boldsymbol{L})$. Projections of $G \alpha_{0}$-expressing basal vomeronasal neurons are restricted to the posterior region of the $A O B$ in robo- $2^{+/ l o x}$; Nestin-Cre mice $(\boldsymbol{A}, \boldsymbol{E})(n=4)$. However, in robo- $2^{\text {lox/lox; }}$; Nestin-Cre mice a subset of these projections ectopically innervate the anterior AOB (arrows) $(n=6)(\boldsymbol{B}, \boldsymbol{F}) . \mathrm{G} \alpha_{\mathrm{i} 2}$-expressing axons projecting from apical vomeronasal neurons are restricted to the anterior region of the $A O B$ in both robo- $2^{+/ l o x} ;$ Nestin-Cre $(\mathbf{G}, \boldsymbol{K})(n=4)$ and

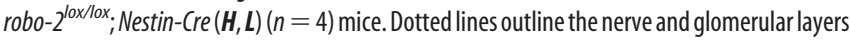
of the $A O B$, and arrowheads indicate the anterior-posterior border as defined by BS lectin staining. Scale bar, $250 \mu \mathrm{m}$. $M, N$, Whole-mount high-magnification views of vomeronasal neuron projections stained with X-gal in adult robo- $2^{+/ l o x}$; Nestin-Cre $(\boldsymbol{M})$ and robo- $2^{\text {lox/lox; }}$; Nestin-Cre $(\boldsymbol{N})$ mice. EC2-expressing vomeronasal sensory neuron axons target the posterior AOB in robo- $2^{+/ l o x}$; Nestin-Cre mice $(\boldsymbol{M})$ while a subset of these fibers mistarget to the anterior $A 0 B$ in robo-2 $2^{\text {lox/lox}}$; Nestin-Cre mice $(\boldsymbol{N})(n=12)$. The AOB is circled and the anterior/posterior border is indicated with a black line.

the olfactory bulb (Fig. 7A,B). Furthermore, whole-mount $\mathrm{X}$-Gal staining of olfactory bulbs revealed that EC2-expressing basal VSN axons form tight fascicles in robo- $2^{+/ l o x}$; Nestin-Cre; EC2-tau-lacZ and robo-2 $2^{\text {lox/lox}}$; Nestin-Cre; EC2-tau-lacZ mice
(Fig. $7 E, F)$. Together, these results suggest that expression of Robo-2 is dispensable for the fasciculation of basal VSN axons but is required for the accurate segregation of some basal VSN axons to the posterior region of the AOB. In contrast, Robo- 1 is not necessary for the targeting of apical and basal VSN axons to the anterior and posterior regions of the $\mathrm{AOB}$, respectively.

Robo-2 expression is required in VSNs for the targeting of basal VSN axons to the posterior AOB

The mistargeting of some basal VSN axons to the anterior region of the AOB in robo-2 $2^{\text {lox/lox}}$; Nestin-Cre mice indicates that Robo-2 expression is required for the targeting of these axons within the AOB. However, since robo-2 is also highly expressed in mitral cells of the AOB, which also express Nestin-Cre, it remains possible that the improper segregation of vomeronasal projections observed could be secondary to defects in the development of the AOB.

To distinguish between these two possibilities, we selectively ablated Robo-2 expression in VSNs by generating robo- 2 conditional mice that express the Cre recombinase under the control of the olfactory marker protein (OMP) promoter (Eggan et al., 2004). In contrast to the early expression of Nestin in the VNO (Merigo et al., 2005), expression of OMP is first observed in very few cells at E16, expands to more cells at $\sim \mathrm{E} 18$ and P0, and is expressed in the majority of cells by P5 (supplemental Fig. 1, available at www.jneurosci.org as supplemental material). In keeping with the late onset of OMP expression in VSNs, a decrease in Robo-2 expression on vomeronasal axons is first detected at $\mathrm{P} 0$ and almost complete loss of protein expression is observed by $\mathrm{P} 5$ in robo-2 ${ }^{\text {lox } / l o x}$ OMP-Cre mice (Fig. 5I-L). Robo-2 expression is completely lost in VSN axons by $\mathrm{P} 10$, but remains expressed in mitral cells of the $\mathrm{AOB}$ in robo- $2^{\text {lox/lox }} \mathrm{OMP}$-Cre mice (Fig. $5 N$ ). The late onset of OMP expression and of Robo-2 ablation in VSNs of these mice suggests that only VSN axons projecting at later times during development, after the initial segregation of early-projecting axons has occurred in the AOB, may be affected in these mice.

Parasagittal sections of the AOB were stained with $G_{\alpha o}$ antibodies and BS lectin (Fig. 8) (data not shown). In contrast to robo- $2^{+/ l o x}$; OMP-Cre mice in which $\mathrm{G}_{\alpha o}$-positive axons are targeted to the posterior region of the $\mathrm{AOB}$, robo- $2^{\text {lox/lox }}$; OMP-Cre mice exhibit ectopic innervation of the anterior $\mathrm{AOB}$ by some $\mathrm{G}_{\alpha \mathrm{o}}$-expressing vomeronasal axons (Fig. $8 A, B$ ). A semiquantitative assessment of mistargeted axons revealed that $\sim 9 \%$ of basal VSN axons innervate the anterior region of the AOB in robo- $2^{\text {lox } / l o x}$; OMP-Cre in contrast to $28 \%$ in robo-2 $2^{\text {lox/lox }}$; Nestin-Cre mice. Whole-mount X-Gal staining analysis on AOBs from robo-2 $2^{\text {lox/lox }}$; $O M P$-Cre EC2-tau-lacZ mice revealed that a substantial fraction of lacZ-positive axons innervate the anterior region of the AOB in these mice (Fig. $8 N$ ). Ectopic innervation of the anterior region of the AOB by lacZ-positive fibers is also observed in parasagittal sections of the AOB from robo-2 $2^{\text {lox/lox }}$; OMP-Cre; EC2-tau-lacZ mice stained with $\beta$-galactosidase antibodies (Fig. $8 F$ ). These lacZ-positive fibers terminate in OMP-positive glomeruli in the anterior region of the $\mathrm{AOB}$ (Fig. $8 \mathrm{~L}$ ). The defects observed in the targeting of $\mathrm{G}_{\alpha \mathrm{o}}$-expressing axons are less severe in robo- $2^{\text {lox/lox; }}$ OMP-Cre than in robo- $2^{\text {lox/lox }}$; Nestin-Cre, which is likely due to the ablation of Robo-2 expression at a later time point during development of these projections in the robo- $2^{\text {lox/lox }}$; OMP-Cre mice. Alternatively, Robo-2 expression in neurons other than VSNs may also contribute in part to the targeting of basal VSN axons to the AOB.

In contrast to $\mathrm{G}_{\alpha \mathrm{o}}$-positive projections from basal VSNs, $\mathrm{G}_{\alpha \mathrm{i} 2}{ }^{-}$ expressing projections from apical VSNs segregate appropriately 
to the anterior region of the $\mathrm{AOB}$ in robo$2^{\text {lox/lox }}$; OMP-Cre mice (Fig. $8 D$ ). Furthermore, apical VSN axons expressing the vomeronasal receptor VN12 also project to their correct target region in these mice (Fig. $8 H, P$ ). As observed in robo- $2^{\text {lox } / l o x}$; Nestin-Cre mice, vomeronasal axons are tightly fasciculated in robo-2 $2^{\text {lox } / l o x}$; OMPCre mice (Fig. 7D, H).

Together, these results demonstrate that expression of Robo-2 in VSNs is critical for the accurate targeting of a portion of basal VSN axons to the posterior region of the AOB. Furthermore, they indicate that Robo-2 is required in axons projecting later during development for proper targeting to the AOB.

Differential contributions of Slits to the targeting of basal vomeronasal axons The expression of all three Slit family members in the AOB suggests they may all be implicated in the Robo-2-mediated guidance of basal VSN axons in the AOB and may contribute to the formation of a previously described Slit protein gradient in the AOB (Knöll et al., 2003). To determine which Slit family members are involved in directing the targeting of basal VSN axons, we analyzed the projections of EC2-positive VSN axons in mice lacking expression of different combinations of Slits. As we have previously reported (Cloutier et al., 2004), ablation of Slit-1 expression leads to mistargeting of some EC2-postive axons to the anterior region of the AOB in all mice analyzed, demonstrating a requirement for Slit-1 in the targeting of these axons (Fig. 9D, $H$ ). Furthermore, mistargeted axons are also observed in a subset of slit-1 ${ }^{+/-}$mice (3 of 6 ), suggesting that the level of Slit-1 expression may be important for directing these axons (Fig. 9C,H). The perinatal death of slit-2 $2^{-1-}$ mice precluded us from examining the targeting accuracy of vomeronasal projections in these animals. Nonetheless, we evaluated the contribution of slit- 2 to this process by assessing the targeting accuracy of EC2-expressing axons in 1) slit-2 $\left.2^{+/-}, 2\right)$ slit- $1^{+/-}$; slit-2 $2^{+/-}$, and 3 ) slit- $1^{-/-}$; slit- $2^{+/-}$mice (Fig. 9E, F,H). In slit$2^{+/-}$mice, one out of four animals showed a significant number of ectopic $\beta$-galactosidase-positive glomeruli in the anterior region of the AOB. Interestingly, while ablation of one allele of slit-2 in slit $-1^{+/-}$mice did not dramatically increase the number of ectopic $\beta$-galactosidase-positive glomeruli observed in each mouse, the mistargeting defects were observed in all slit-1 ${ }^{+/-}$; slit $-2^{+/-}$mice analyzed $(n=5)$ compared to a subset of slit- $1^{+/-}$ mice (Fig. 9C, F, H).

Since slit-3 is also expressed in the AOB, we examined the requirement for Slit-3 in the targeting of EC2-expressing axons. In contrast to the defects observed in slit- $1^{-/-}$and slit- $1^{+/-}$; slit- $2^{+/-}$mice, we did not detect ectopic innervation of the anterior region of the $\mathrm{AOB}$ in any of the slit- $3^{-1-}$ mice analyzed by either $\beta$-galactosidase immunostaining $(n=3)$ or whole-mount robo-2; OMP-Cre

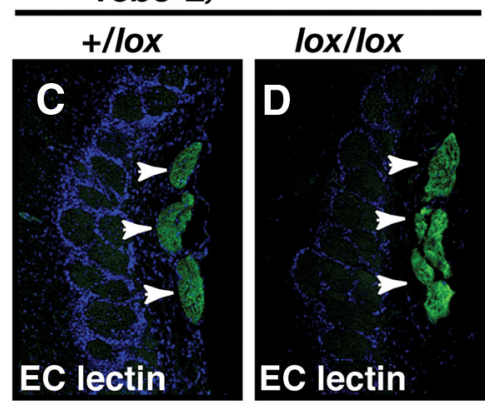

robo-2 lox/lox; Nestin-Cre; EC2-tau-lacZ

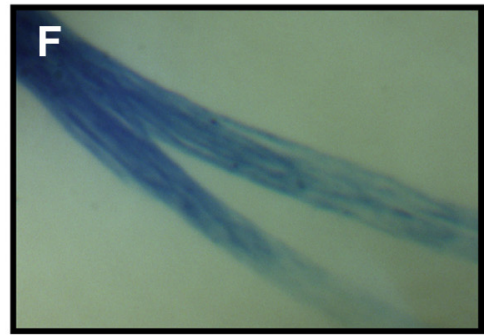

robo-2 lox/lox; OMP-Cre; EC2-tau-lacZ

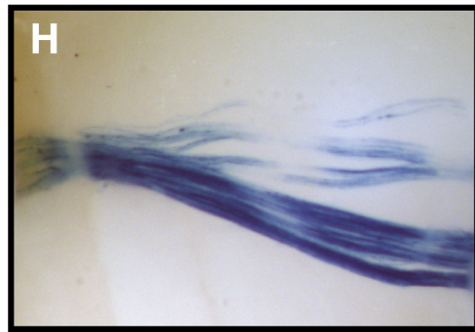

Figure 7. The vomeronasal nerve remains tightly fasciculated in robo-2 $2^{\text {lox/lox; }}$ Nestin-Cre and robo-2 $2^{\text {lox/lox }}$;OMP-Cre mice. $A-D$, Coronal sections of olfactory bulbs from adult robo-2 $2^{+/ 10 x}$; Nestin-Cre (A), robo-2 $2^{\text {lox/lox; }}$ Nestin-Cre (B), robo-2 ${ }^{+/ 10 x}$; OMP-Cre (C) and robo-2 $2^{10 x / l o x} ;$ OMP-Cre (D) mice were stained with EC lectin. The vomeronasal nerve is tightly fasciculated in all mice (arrowtions stained with X-gal in adult robo-2 $2^{+/ 10 x} ;$ Nestin-Cre; EC2-tau-lacZ (E), robo-2 $2^{\text {lox/lox; }}$ Nestin-Cre; EC2-tau-lacZ (F), robo-2 $2^{+/ l o x}$, mice $(n=6)$. D, Dorsal; $V$, ventral; $P$, posterior; $A$, anterior.

X-Gal staining $(n=5)$ (Fig. 9B,H) (data not shown). Furthermore, deletion of both slit-1 and slit-3 did not significantly change the number of ectopic $\beta$-galactosidase-positive glomeruli observed in the anterior region of the AOB when compared to slit- $1^{-1-}$ mice suggesting that slit-3 is dispensable for the segregation of basal vomeronasal axons to the posterior region of the AOB. Together, our results suggest that both Slit-1 and Slit-2 contribute to the Robo-2-mediated segregation of basal VSN axons to the posterior region of the $A O B$, but that Slit-3 is dispensable.

\section{Discussion}

The detection of sensory inputs by the accessory olfactory system requires the formation of accurate connections between VSNs and second order neurons located in the AOB. VSNs express vomeronasal receptors of either the V1R or V2R family. While the detection of compounds by V1R-expressing VSNs is believed to control the onset of puberty, estrus induction, and male-tomale aggression, the activation of V2R-expressing VSNs has been proposed to regulate mate recognition (Leinders-Zufall et al., 2000, 2004; Boschat et al., 2002; Del Punta et al., 2002; Stowers 
robo-2 +/lox; OMP-Cre
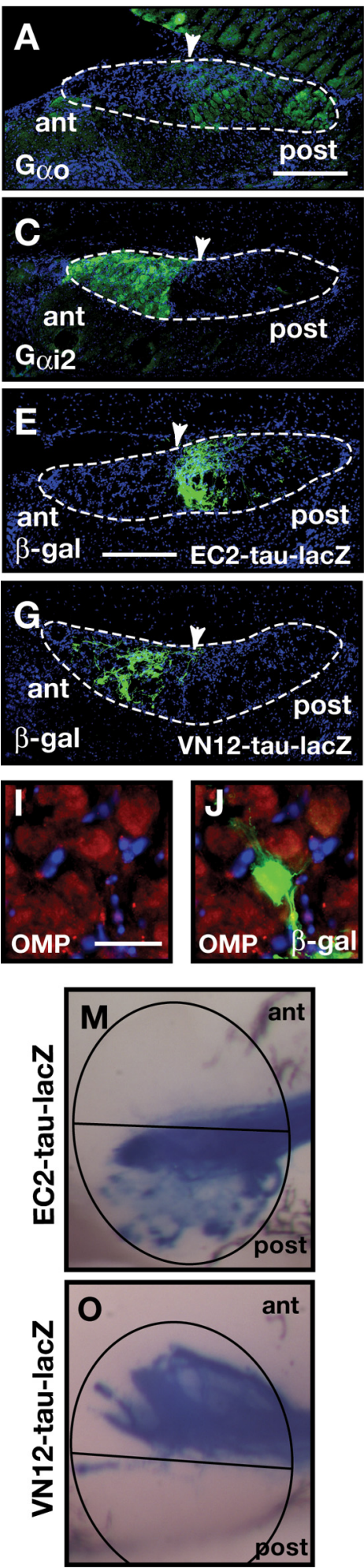
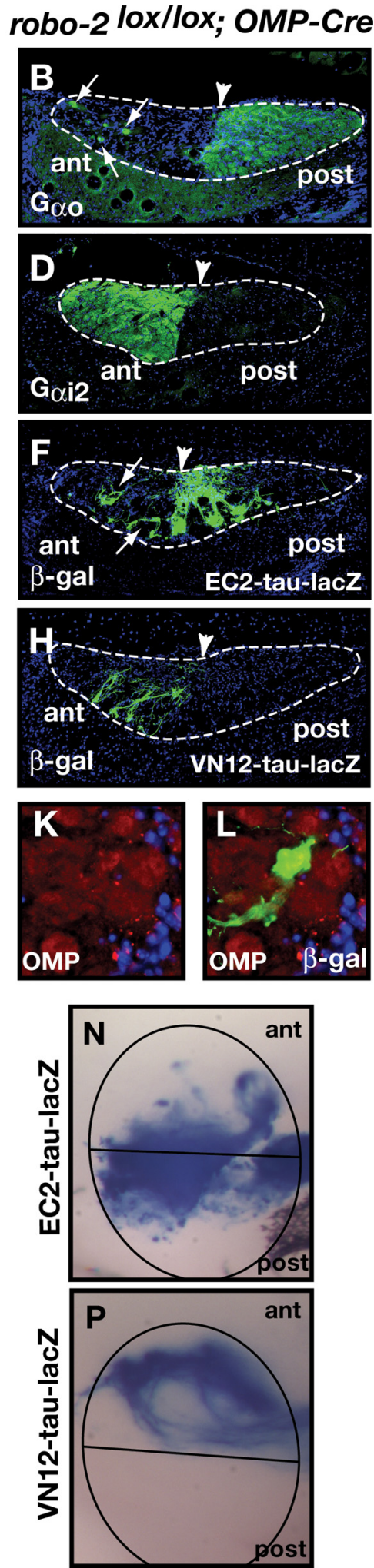

Figure 8. Ablation of Robo-2 expression in vomeronasal sensory neurons leads to mistargeting of a portion of basal vomeronasal neuron axons to the anterior $A O B$. $A-D$, Parasagittal $A O B$ sections of adult robo-2 $2^{+/ l o x} ;$ OMP-Cre $(\boldsymbol{A}, \boldsymbol{C})$ and robo- $2^{\text {lox/lox }}$ OMP-Cre $(\boldsymbol{B}, \boldsymbol{D})$ mice were stained with $\mathrm{G} \alpha_{0}(\boldsymbol{A}, \boldsymbol{B})$ or $\mathrm{G} \alpha_{\mathrm{i} 2}$ antibodies $(\boldsymbol{C}, \boldsymbol{D})$. Projections of $\mathrm{G} \alpha_{0}$-expressing basal vomeronasal neurons are restricted to the posterior region of the $A O B$ in $r o b o-2^{+/ l o x} ; O M P$-Cre mice $(\boldsymbol{A})$. However, in robo- $2^{\text {lox } / l o x} ; O M P$-Cre mice, a subset of these projections ectopically innervate the anterior region of the $\mathrm{AOB}$ (arrows) $(\boldsymbol{B})(n=4)$. $\mathrm{G} \alpha_{\mathrm{i} 2}$-expressing apical vomeronasal neuron axons are restricted to the anterior region of the $A 0 B$ in both robo-2 $2^{+/ l o x} ; 0 M P-C r e(C)$ and robo- $2^{\text {lox/lox }}$ OMP-Cre (D) mice. Dotted lines outline the nerve and glomerular layers of the $A O B$ and arrowheads indicate the anterior-posterio border as defined by BS lectin staining (data not shown). Scale bar, $250 \mu \mathrm{m}$. $\boldsymbol{E}-\boldsymbol{H}$, Parasagittal AOB sections of adult robo-2 $2^{+/ l o x} ;$ OMP-CreEC2; EC2-tau-lacZ(E), and robo-2 ${ }^{\text {lox/lox }} ;$ OMP-Cre; EC2-tau-lacZ(F), robo-2 ${ }^{+1 l o x} ;$ OMP-Cre; VN12-tau-lacZ(G), and

and Marton, 2005). The spatial segregation of V1R- and V2R-expressing VSN cell bodies within the vomeronasal organ is conserved at the level of their projections in the anterior and posterior regions of the $\mathrm{AOB}$ and may be critical for the modulation of these behaviors.

Our results show that expression of Robo-2, but not Robo-1, in VSNs is necessary for the segregation of a portion of basal VSN axons to the posterior region of the AOB. Furthermore, the Robo-2 ligands Slit-1, Slit-2, and Slit-3 are all expressed in the $\mathrm{AOB}$ but our results showing that some basal VSN axons are mistargeted to the anterior region of the $\mathrm{AOB}$ in slit- $1^{-/-}$and slit- ${ }^{+/-}$; slit- $2^{+/-}$, but not in $s$ lit $-3^{-/-}$mice, indicate that they have different contributions to the Robo-2-mediated targeting of VSN axons. Together our results demonstrate that Robo-2 is the Slit receptor that controls the targeting of basal VSN axons in the AOB.

Expression of Robo and Slit family members in the accessory olfactory system Previous examination of the expression of Robo family members in the VNO had

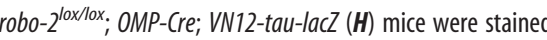
with anti- $\beta$-galactosidase. EC2-expressing axons are restricted to the posterior region of the $A O B$ in robo- $2^{+10 x}$; OMPCre; EC2-tau-lacZ mice $(\boldsymbol{E})$ while a subset of EC2-positive fibers are mistargeted to the anterior region of the $A O B$ in robo- $2^{l o x / l o x}$, OMP-Cre; EC2-tau-lacZ mice (arrows) $(\boldsymbol{F})(n=9)$. In contrast, VN12-expressing axons are restricted to the anterior region of the AOB in both robo-2 ${ }^{+/ 10 x}$; OMP-Cre; VN12-tau-lacZ (G) and robo-2 $2^{\text {lox/lox }}$ OMP-Cre; VN12-tau-lacZ $(\boldsymbol{H})$ mice $(n=4)$. Dotted lines outline the nerve and glomerular layers of the $A O B$ and arrowheads indicate the anterior-posterior border as defined by BS lectin staining (data not shown). Scale bar, $250 \mu \mathrm{m} . \boldsymbol{I}-\boldsymbol{L}$, Sagittal sections of the accessory olfactory bulb from adult

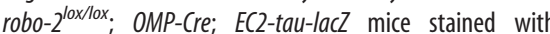
$\beta$-galactosidase (green) and OMP (red) antibodies. Highmagnification examples of EC2-positive axons targeting correctly in an OMP-positive glomerulus in the posterior region of the $A O B(I, J)$ and of EC2-positive axons mistargeting in an OMP-positive glomerulus in the anterior region of the $A O B$ $(\boldsymbol{K}, \boldsymbol{L})$ in these mice. Scale bar, $50 \mu \mathrm{m} . \boldsymbol{M}-\boldsymbol{P}$, Whole-mount highmagnification views of vomeronasal neuron projections stained with X-gal in adult robo-2 ${ }^{+1 / 0 x}$; OMP-Cre; EC2-tau-lacZ $(M)$, robo-2 ${ }^{\text {lox/lox; }}$ OMP-Cre; EC2-tau-lacZ $(\boldsymbol{N})$, robo-2 ${ }^{+/ 10 x}$; OMP-Cre; VN12-tau-lacZ(0), and robo-2 ${ }^{\text {lox/lox } ; O M P-C r e ; ~ V N 12-~}$ tau-lacZ $(\boldsymbol{P})$ mice. EC2-expressing vomeronasal sensory neuron axons target the posterior $\mathrm{AOB}$ in robo-2 ${ }^{+/ 10 x}$; OMP-Cre; EC2-tau-lacZ mice $(\boldsymbol{M})$ while a subset of these fibers mistarget to the anterior AOB in robo-2 $2^{\text {lox/lox; }}$ OMP-Cre; EC2-tau-lacZ mice $(n=8)(\boldsymbol{N})$. VN12-expressing vomeronasal sensory neuron axons innervate the anterior region of the $A O B$ in both robo-2 ${ }^{+/ 10 x}$; OMP-Cre VN12-tau-lacZ (0) and robo-2 $2^{\text {lox/lox }}$; OMP-Cre VN12-tau-lacZ $(\boldsymbol{P})$ mice $(n=3)$. The AOB is circled and the anterior/posterior border is indicated with a black line. 
shown that both Robo-1 and Robo-2 are expressed in VSNs and that Robo-2 expression is restricted to VSNs located in the basal region of the VNO (Fig. $2 B, D, G$ ) (Knöll et al., 2003; Cloutier et al., 2004). Our analyses revealed that Robo- 1 is expressed at low levels in VSNs throughout development and in the adult but it is not required for the segregation of apical and basal VSN axons to the anterior and posterior regions of the $\mathrm{AOB}$, respectively (Figs. 1, 4). In contrast to Robo-1, Robo-2 is strictly expressed in basal VSNs and its expression level varies within this population of neurons (Fig. 2).

The expression of Slit family proteins in the AOB may promote the targeting of Robo-2-expressing vomeronasal axons to the posterior AOB. It has been reported that a high anterior to low posterior gradient of Slit proteins is present in the $\mathrm{AOB}$ that could serve to prevent Robo-2expressing axons from entering the anterior part of the AOB (Knöll et al., 2003). Our results show that slit-1 is strongly expressed in a subset of cells located at the anterior tip of the AOB while slit- 2 is expressed at low levels throughout the mitral cell layer of the AOB during development (Fig. 3). Interestingly, slit-3 is expressed at higher levels in the posterior part of the $\mathrm{AOB}$ and becomes restricted to this region by E18 (Fig. 3C,F,I,L). This result is different from the previously reported observation that slit-3 is expressed in a subset of cells located in the anterior tip of the AOB. This discrepancy may be due to our use of two slit-3 cRNA probes that differ from the ones used by Knöll et al. Nonetheless, our observation that the pattern of slit-3 expression in the AOB is absent in slit- $3^{-/-}$mice indicates that the cRNA probe used in our studies was very specific. The patterns of expression of slits suggest that while Slit-1 and Slit-2 may direct the growth of Robo-2-positive axons to the posterior region of the $A O B$ by restricting their entry into the anterior region of the $\mathrm{AOB}$, it is likely that Slit-3 may play a different role in the targeting of these axons. Potential modes of Slit-3 action are discussed below.

\section{Robo-2 directs the anterior-posterior zonal segregation of basal vomeronasal sensory neuron axons}

The expression of Robo-2 in basal VSNs combined with the expression of Slits in the AOB suggested that Robo- 2 controls the segregation of these axons to the posterior region of the AOB. To test this possibility, we ablated Robo-2 expression early during development of vomeronasal projections. Our analyses revealed that ablation of Robo-2 expression in neurons leads to mistargeting of a portion of $\mathrm{G}_{\alpha \mathrm{o}}$-expressing axons to the anterior region of the AOB (Fig. 6 B, F). Since Robo-2 is expressed in both VSNs and in mitral cells of the AOB, the requirement for Robo-2 on vomeronasal axons was evaluated by ablating Robo-2 expression specifically in VSNs using OMP-Cre mice (Fig. $8 B$ ). These experiments demonstrated that Robo-2 expression within VSNs is required to promote the segregation of a portion of basal VSN axons to the posterior region of the AOB.

The defects observed in the targeting of basal vomeronasal axons in mice lacking Robo-2 expression are similar to defects observed in slit- $1^{-1-}$ mice suggesting that Slit-Robo-2 interactions direct the segregation of VSN axons in the AOB. In addition to slit-1, both slit-2 and slit-3 are expressed in the AOB at the time during development when VSN axons project to the AOB. Our observation that deletion of one slit- 2 allele in slit- $1^{+/-}$mice increases the penetrance of the targeting defects observed in a subset of slit- $1^{+/-}$mice suggests that Slit-2, in addition to Slit-1, also contributes to the segregation of basal vomeronasal axons to the posterior region of the AOB (Fig. $9 F, H$ ). In contrast to Slit-1 and Slit-2, ablation of Slit-3 expression did not lead to significant defects in the segregation of basal VSN axons to the posterior region of the $\mathrm{AOB}$ (Fig. 9 $\mathrm{B}, \mathrm{H}$ ). Nonetheless, it is interesting to note that slit-3 is more highly expressed in the posterior region of the AOB starting as early as E14, and becomes restricted to mitral cells located in the most posterior part of the AOB by E18. It is possible that subsets of basal VSN axons express different levels of 
Robo-2 and respond differently to Slit-3 in the AOB. In keeping with this possibility, we have observed that robo-2 is expressed at different levels among basal VSNs (Fig. 2C,J). Slit-3 could therefore control the glomerular targeting of subsets of basal VSNs axons within the posterior region of the AOB. It was recently demonstrated that basal VSN axons segregate into two subdomains within the posterior region of the $\mathrm{AOB}$ according to their expression of nonclassical class I MHC genes of the H2-Mv gene family (Ishii and Mombaerts, 2008). Basal VSNs expressing H2Mvs project their axons to the most posterior region of the AOB while axons that do not express $H 2-\mathrm{Mv}$ project to a region of the posterior $\mathrm{AOB}$ that is adjacent to the anterior-posterior border. It is therefore possible that these two subsets of basal VSNs express different levels of Robo-2 and respond differently to Slit-3 expressed in the most posterior region of the AOB. To examine this possibility, it will be necessary to assess the targeting of axons that innervate glomeruli exclusively located close to the anteriorposterior border of the AOB in slit- $3^{-1-}$ mice.

\section{Axon guidance cues in the targeting of vomeronasal axons}

The segregation of axons projecting from basal and apical VSN axons within the AOB relies on the action of several families of axon guidance cues. A combination of attractive forces through Ephrin-Eph interactions, and repulsive forces through secreted semaphorins and Npn-2, promotes the segregation of apical VSN axons to the anterior region of the AOB (Knöll et al., 2001; Cloutier et al., 2002, 2004; Walz et al., 2002; Walz et al., 2007). We have now shown that slit-Robo-2 interactions are required for the segregation of basal VSN axons to the posterior region of the AOB. Based on our observation that only a portion of basal VSN axons mistargets to the anterior region of the AOB upon ablation of Robo-2 expression, it is likely that other factors, possibly an attractant, also contribute to the targeting of these axons to the posterior region of the AOB. An added level of complexity in the mechanisms underlying the formation of the glomerular map in the $\mathrm{AOB}$ has been suggested by the recent demonstration that the posterior region of the $\mathrm{AOB}$ may be subdivided into two regions innervated by subsets of basal VSN axons based on the pattern of expression of H2-Mv genes in these neurons (Ishii and Mombaerts, 2008). While Robo-2 may contribute to the targeting of these subsets of axons within the posterior region of the AOB by responding to Slits, it is also possible that the differential expression of cell adhesion molecules on subsets of basal VSN axons promotes their convergence to different regions within the posterior AOB, as previously shown in the main olfactory system (Serizawa et al., 2006; Kaneko-Goto et al., 2008). Together, our results demonstrate that Robo-2 expression in basal VSN axons is required for their segregation within the AOB. Future studies should reveal the effect of improper wiring of the accessory olfactory system on mouse behaviors regulated by VSNs.

\section{References}

Andrews W, Barber M, Hernadez-Miranda LR, Xian J, Rakic S, Sundaresan V, Rabbitts TH, Pannell R, Rabbitts P, Thompson H, Erskine L, Murakami F, Parnavelas JG (2008) The role of Slit-Robo signaling in the generation, migration and morphological differentiation of cortical interneurons. Dev Biol 313:648-658.

Belluscio L, Koentges G, Axel R, Dulac C (1999) A map of pheromone receptor activation in the mammalian brain. Cell 97:209-220.

Boschat C, Pélofi C, Randin O, Roppolo D, Lüscher C, Broillet MC, Rodriguez I (2002) Pheromone detection mediated by a V1r vomeronasal receptor. Nat Neurosci 5:1261-1262.

Brose K, Bland KS, Wang KH, Arnott D, Henzel W, Goodman CS, TessierLavigne M, Kidd T (1999) Slit proteins bind Robo receptors and have an evolutionarily conserved role in repulsive axon guidance. Cell 96:795-806.

Cho JH, Lépine M, Andrews W, Parnavelas J, Cloutier JF (2007) Requirement for Slit-1 and Robo-2 in zonal segregation of olfactory sensory neuron axons in the main olfactory bulb. J Neurosci 27:9094-9104.

Cloutier JF, Giger RJ, Koentges G, Dulac C, Kolodkin AL, Ginty DD (2002) Neuropilin-2 mediates axonal fasciculation, zonal segregation, but not axonal convergence, of primary accessory olfactory neurons. Neuron 33:877-892.

Cloutier JF, Sahay A, Chang EC, Tessier-Lavigne M, Dulac C, Kolodkin AL, Ginty DD (2004) Differential requirements for semaphorin 3F and Slit-1 in axonal targeting, fasciculation, and segregation of olfactory sensory neuron projections. J Neurosci 24:9087-9096.

Del Punta K, Leinders-Zufall T, Rodriguez I, Jukam D, Wysocki CJ, Ogawa S, Zufall F, Mombaerts P (2002) Deficient pheromone responses in mice lacking a cluster of vomeronasal receptor genes. Nature 419:70-74.

Dulac C, Axel R (1995) A novel family of genes encoding putative pheromone receptors in mammals. Cell 83:195-206.

Dulac C, Wagner S (2006) Genetic analysis of brain circuits underlying pheromone signaling. Annu Rev Genet 40:449-467.

Eggan K, Baldwin K, Tackett M, Osborne J, Gogos J, Chess A, Axel R, Jaenisch $\mathrm{R}$ (2004) Mice cloned from olfactory sensory neurons. Nature 428: $44-49$.

Fouquet C, Di Meglio T, Ma L, Kawasaki T, Long H, Hirata T, Tessier-Lavigne M, Chédotal A, Nguyen-Ba-Charvet KT (2007) Robol and robo2 control the development of the lateral olfactory tract. J Neurosci 27: 3037-3045.

Grieshammer U, Le M, Plump AS, Wang F, Tessier-Lavigne M, Martin GR (2004) SLIT2-mediated ROBO2 signaling restricts kidney induction to a single site. Dev Cell 6:709-717.

Halpern M, Shapiro LS, Jia C (1995) Differential localization of G proteins in the opossum vomeronasal system. Brain Res 677:157-161.

Halpern M, Jia C, Shapiro LS (1998) Segregated pathways in the vomeronasal system. Microsc Res Tech 41:519-529.

Herrada G, Dulac C (1997) A novel family of putative pheromone receptors in mammals with a topographically organized and sexually dimorphic distribution. Cell 90:763-773.

Ishii T, Mombaerts P (2008) Expression of nonclassical class I major histocompatibility genes defines a tripartite organization of the mouse vomeronasal system. J Neurosci 28:2332-2341.

Jia C, Halpern M (1996) Subclasses of vomeronasal receptor neurons: differential expression of $\mathrm{G}$ proteins (Gi alpha 2 and $\mathrm{G}(\mathrm{o}$ alpha)) and segregated projections to the accessory olfactory bulb. Brain Res 719:117-128.

Kaneko-Goto T, Yoshihara S, Miyazaki H, Yoshihara Y (2008) BIG-2 mediates olfactory axon convergence to target glomeruli. Neuron 57:834-846.

Knöll B, Zarbalis K, Wurst W, Drescher U (2001) A role for the EphA family in the topographic targeting of vomeronasal axons. Development 128:895-906.

Knöll B, Schmidt H, Andrews W, Guthrie S, Pini A, Sundaresan V, Drescher $\mathrm{U}$ (2003) On the topographic targeting of basal vomeronasal axons through Slit-mediated chemorepulsion. Development 130:5073-5082.

Leinders-Zufall T, Lane AP, Puche AC, Ma W, Novotny MV, Shipley MT, Zufall F (2000) Ultrasensitive pheromone detection by mammalian vomeronasal neurons. Nature 405:792-796.

Leinders-Zufall T, Brennan P, Widmayer P, S PC, Maul-Pavicic A, Jäger M, Li XH, Breer H, Zufall F, Boehm T (2004) MHC class I peptides as chemosensory signals in the vomeronasal organ. Science 306:1033-1037.

Lu W, van Eerde AM, Fan X, Quintero-Rivera F, Kulkarni S, Ferguson H, Kim HG, Fan Y, Xi Q, Li QG, Sanlaville D, Andrews W, Sundaresan V, Bi W, Yan J, Giltay JC, Wijmenga C, de Jong TP, Feather SA, Woolf AS, et al. (2007) Disruption of ROBO2 is associated with urinary tract anomalies and confers risk of vesicoureteral reflux. Am J Hum Genet 80:616-632.

Marillat V, Cases O, Nguyen-Ba-Charvet KT, Tessier-Lavigne M, Sotelo C, Chédotal A (2002) Spatiotemporal expression patterns of slit and robo genes in the rat brain. J Comp Neurol 442:130-155.

Matsunami H, Buck LB (1997) A multigene family encoding a diverse array of putative pheromone receptors in mammals. Cell 90:775-784.

Merigo F, Mucignat-Caretta C, Zancanaro C (2005) Timing of neuronal intermediate filament proteins expression in the mouse vomeronasal organ during pre- and postnatal development. An immunohistochemical study. Chem Senses 30:707-717.

Mombaerts P, Wang F, Dulac C, Chao SK, Nemes A, Mendelsohn M, 
Edmondson J, Axel R (1996) Visualizing an olfactory sensory map. Cell 87:675-686.

Pantages E, Dulac C (2000) A novel family of candidate pheromone receptors in mammals. Neuron 28:835-845.

Plachez C, Andrews W, Liapi A, Knoell B, Drescher U, Mankoo B, Zhe L, Mambetisaeva E, Annan A, Bannister L, Parnavelas JG, Richards LJ, Sundaresan V (2008) Robos are required for the correct targeting of retinal ganglion cell axons in the visual pathway of the brain. Mol Cell Neurosci 37:719-730.

Plump AS, Erskine L, Sabatier C, Brose K, Epstein CJ, Goodman CS, Mason CA, Tessier-Lavigne M (2002) Slit1 and Slit2 cooperate to prevent premature midline crossing of retinal axons in the mouse visual system. Neuron 33:219-232.

Rodriguez I, Del Punta K, Rothman A, Ishii T, Mombaerts P (2002) Multiple new and isolated families within the mouse superfamily of V1r vomeronasal receptors. Nat Neurosci 5:134-140.

Ryba NJ, Tirindelli R (1997) A new multigene family of putative pheromone receptors. Neuron 19:371-379.

Serizawa S, Miyamichi K, Takeuchi H, Yamagishi Y, Suzuki M, Sakano H (2006) A neuronal identity code for the odorant receptor-specific and activity-dependent axon sorting. Cell 127:1057-1069.
Stowers L, Marton TF (2005) What is a pheromone? Mammalian pheromones reconsidered. Neuron 46:699-702.

Tanaka M, Treloar H, Kalb RG, Greer CA, Strittmatter SM (1999) $G_{0}$ protein-dependent survival of primary accessory olfactory neurons. Proc Natl Acad Sci U S A 96:14106-14111.

Tronche F, Kellendonk C, Kretz O, Gass P, Anlag K, Orban PC, Bock R, Klein R, Schütz G (1999) Disruption of the glucocorticoid receptor gene in the nervous system results in reduced anxiety. Nat Genet 23:99-103.

Walz A, Rodriguez I, Mombaerts P (2002) Aberrant sensory innervation of the olfactory bulb in neuropilin-2 mutant mice. J Neurosci 22:40254035.

Walz A, Feinstein P, Khan M, Mombaerts P (2007) Axonal wiring of guanylate cyclase-D-expressing olfactory neurons is dependent on neuropilin 2 and semaphorin 3F. Development 134:4063-4072.

Yuan W, Zhou L, Chen JH, Wu JY, Rao Y, Ornitz DM (1999) The mouse SLIT family: secreted ligands for ROBO expressed in patterns that suggest a role in morphogenesis and axon guidance. Dev Biol 212:290-306.

Yuan W, Rao Y, Babiuk RP, Greer JJ, Wu JY, Ornitz DM (2003) A genetic model for a central (septum transversum) congenital diaphragmatic hernia in mice lacking Slit3. Proc Natl Acad Sci U S A 100:5217-5222.

Zufall F, Leinders-Zufall T (2007) Mammalian pheromone sensing. Curr Opin Neurobiol 17:483-489. 